\title{
Emissions of trace gases and particles from savanna fires in southern Africa
}

\author{
Parikhit Sinha, ${ }^{1}$ Peter V. Hobbs, ${ }^{1}$ Robert J. Yokelson, ${ }^{2}$ Isaac T. Bertschi, ${ }^{2}$ \\ Donald R. Blake, ${ }^{3}$ Isobel J. Simpson, ${ }^{3}$ Song Gao, ${ }^{4}$ Thomas W. Kirchstetter, ${ }^{5}$ \\ and Tica Novakov ${ }^{5}$ \\ Received 15 March 2002; revised 21 August 2002; accepted 22 August 2002; published 21 March 2003.
}

[1] Airborne measurements made on initial smoke from 10 savanna fires in southern Africa provide quantitative data on emissions of 50 gaseous and particulate species, including carbon dioxide, carbon monoxide, sulfur dioxide, nitrogen oxides, methane, ammonia, dimethyl sulfide, nonmethane organic compounds, halocarbons, gaseous organic acids, aerosol ionic components, carbonaceous aerosols, and condensation nuclei $(\mathrm{CN})$. Measurements of several of the gaseous species by gas chromatography and Fourier transform infrared spectroscopy are compared. Emission ratios and emission factors are given for eight species that have not been reported previously for biomass burning of savanna in southern Africa (namely, dimethyl sulfide, methyl nitrate, five hydrocarbons, and particles with diameters from 0.1 to $3 \mu \mathrm{m}$ ). The emission factor that we measured for ammonia is lower by a factor of 4 , and the emission factors for formaldehyde, hydrogen cyanide, and $\mathrm{CN}$ are greater by factors of about 3,20 , and $3-15$, respectively, than previously reported values. The new emission factors are used to estimate annual emissions of these species from savanna fires in Africa and worldwide. INDEX TERMS: 0305 Atmospheric Composition and Structure: Aerosols and particles (0345, 4801); 0315 Atmospheric Composition and Structure: Biosphere/atmosphere interactions; 0322 Atmospheric Composition and Structure: Constituent sources and sinks; 0345 Atmospheric Composition and Structure: Pollution-urban and regional (0305); KEYWORDS: trace gas emissions, biomass fires, smoke, savanna fires, emissions from fires, particle emissions

Citation: Sinha, P., P. V. Hobbs, R. J. Yokelson, I. T. Bertschi, D. R. Blake, I. J. Simpson, S. Gao, T. W. Kirchstetter, and T. Novakov, Emissions of trace gases and particles from savanna fires in southern Africa, J. Geophys. Res., 108(D13), 8487, doi:10.1029/2002JD002325, 2003.

\section{Introduction}

[2] Savanna fires are the largest global source of biomass burning emissions, and tropical Africa contains about two thirds of the world's savanna [Hao and Liu, 1994; Andreae et al., 1996]. Savanna burning is a source of a wide variety of chemical species that are important in global atmospheric chemistry, including carbon monoxide $(\mathrm{CO})$, nitrogen oxides $\left(\mathrm{NO}_{\mathrm{x}}\right)$, sulfur dioxide $\left(\mathrm{SO}_{2}\right)$, hydrocarbons, halocarbons, oxygenated organic compounds, and particles [ $\mathrm{Del}$ mas, 1982; Crutzen and Andreae, 1990; Ward and Hardy, 1991; Hurst et al., 1994; Blake et al., 1996; Yokelson et al., 1996; Ferek et al., 1998]. Gases with high global warming potentials, such as methane $\left(\mathrm{CH}_{4}\right)$ and nitrous oxide $\left(\mathrm{N}_{2} \mathrm{O}\right)$,

\footnotetext{
${ }^{1}$ Department of Atmospheric Sciences, University of Washington, Seattle, Washington, USA.

${ }^{2}$ Department of Chemistry, University of Montana, Missoula, Montana, USA.

${ }^{3}$ Department of Chemistry, University of California, Irvine, California, USA.

${ }^{4}$ Department of Chemistry, University of Washington, Seattle, Washington, USA.

Sawrence Berkeley National Laboratory, Berkeley, California, USA.

Copyright 2003 by the American Geophysical Union. 0148-0227/03/2002JD002325\$09.00
}

are released in globally minor but nontrivial quantities by biomass burning [Logan et al., 1981; Quay et al., 1991; Hurst et al., 1994; Cofer et al., 1996; Andreae et al., 1996]. Methyl chloride $\left(\mathrm{CH}_{3} \mathrm{Cl}\right)$, methyl bromide $\left(\mathrm{CH}_{3} \mathrm{Br}\right)$, and other halocarbons released by biomass burning may contribute to stratospheric ozone $\left(\mathrm{O}_{3}\right)$ depletion [Blake et al., 1996; McKenzie et al., 1996]. Organic and black carbon particles emitted from biomass burning play important roles in the Earth's radiation balance [Cachier et al., 1996]. Gasto-particle conversion of organic compounds, $\mathrm{NO}_{\mathrm{x}}$, and $\mathrm{SO}_{2}$ may alter the radiative and cloud nucleating properties of smoke aerosols [Reid et al., 1998]. Acids in smoke from biomass fires, such as acetic acid $\left(\mathrm{CH}_{3} \mathrm{COOH}\right)$, formic acid $(\mathrm{HCOOH})$, nitric acid $\left(\mathrm{HNO}_{3}\right)$, and sulfuric acid $\left(\mathrm{H}_{2} \mathrm{SO}_{4}\right)$, can alter the $\mathrm{pH}$ of precipitation [Lacaux et al., 1991; Yokelson et al., 1996]. Organic compounds and CO emitted from biomass fires have been shown to react photochemically in the presence of nitrogen oxides to produce increases in ozone mixing ratios. In the case of African biomass fires, these emissions lead to widespread increases in the concentration of $\mathrm{O}_{3}$ over the South Atlantic region [Fishman et al., 1991, 1996; Thompson et al., 1996].

[3] In August and September 2000, the Cloud and Aerosol Research Group (CARG) from the University of Washington (UW), with its Convair-580 research aircraft, 
participated in the Southern African Regional Science Initiative 2000 (SAFARI 2000) field project. One of the goals of SAFARI 2000 is to characterize and quantify pyrogenic emissions in southern Africa. This paper focuses on this goal by using measurements obtained in numerous plume penetrations above 10 savanna fires in the tropical and subtropical regions of southern Africa (South Africa, Zambia, Mozambique, and Botswana) to derive emission ratios and emission factors for many trace gases and particles. The subsequent evolution of these trace gases and particles in the smoke from one of these fires is described by Hobbs et al. [2003].

\section{Sampling Techniques and Instrumentation}

[4] All of the measurements described in this paper were obtained aboard the UW Convair-580 research aircraft. A complete list of the instruments aboard the UW Convair580 aircraft, and the individuals responsible for the various measurements, is given in Appendix A. Only the instruments and techniques that provided measurements presented in this paper are described here.

[5] Aerosol samples collected on quartz filters (Pallflex 2500 QAT-UP) were used to determine the concentration of particulate carbon. The quartz filters were baked before use at $800^{\circ} \mathrm{C}$ for at least $6 \mathrm{~h}$ to remove carbonaceous impurities, and then were analyzed for total carbon (TC) content using the Evolved Gas Analysis (EGA) method described by Novakov [1981, 1982]. In EGA, a portion of the filter is heated at a constant rate $\left(40^{\circ} \mathrm{C}\right.$ min $^{-1}$ in this case) from 50 to $800^{\circ} \mathrm{C}$ in an oxygen atmosphere. The carbon-containing gases that evolve from the sample are converted to carbon dioxide $\left(\mathrm{CO}_{2}\right)$ over a manganese dioxide catalyst maintained at $800^{\circ} \mathrm{C}$. The $\mathrm{CO}_{2}$ was subsequently measured with a nondispersive infrared analyzer (Beckman Model 870). A plot of the $\mathrm{CO}_{2}$ concentration versus temperature is called a thermogram. The area under a thermogram is proportional to the TC content of the analyzed sample. The tandem filter method described by Turpin et al. [1994] and Kirchstetter et al. [2001] was used to adjust estimates of TC for the positive sampling artifact that results from the adsorption of organic gases on the quartz filters. Black carbon (BC) concentrations were estimated with an optical transmission technique similar to that described by Rosen and Novakov [1983]. This method compares the attenuation of white light through a loaded filter relative to that of a blank filter. The relationship between optical attenuation (ATN) and the BC concentration $\left(\mu \mathrm{g} \mathrm{cm}^{-2}\right)$ is given by ATN $=\sigma \cdot \mathrm{BC}$, where $\operatorname{ATN}=-100 \ln \left(\mathrm{I} / \mathrm{I}_{\mathrm{o}}\right)$, where $\mathrm{I}_{\mathrm{o}}$ and $\mathrm{I}$ are the transmitted light intensities through the blank and loaded filters, respectively, and $\sigma$ is the mass absorption cross-section for BC deposited on quartz $\left(\mathrm{m}^{2} \mathrm{~g}^{-1}\right)$ [Gundel et al., 1984]. A value of $20 \mathrm{~m}^{2}$ $\mathrm{g}^{-1}$ was used for the mass absorption cross-section. Further information on the EGA technique used here, and the results obtained, are given by Kirchstetter et al. [2003].

[6] Particles were also collected on Teflon (Gelman Sciences Teflo membrane, $2.0 \mu \mathrm{m}$ pore size) filters. The Teflon filters were weighed before and after particle sampling in a humidity and temperature controlled chamber $(\mathrm{RH}=40 \%, \mathrm{~T}=293 \mathrm{~K})$ to determine the masses of dry particulate matter (PM) collected on the filters. From control and field blank filters, the uncertainty of the total dry PM measured with these filters was estimated to be $\pm 6 \mu \mathrm{g}$. By comparison, the typical dry PM loading for smoke aerosol samples was always greater than $100 \mu \mathrm{g}$.

[7] After gravimetric analysis, the particles collected on the Teflon filters were extracted in deionized water (HPLC grade) and analyzed by a standard ion chromatography system (Dionex DX 500). This analysis yielded mass concentrations of chlorine, nitrate and sulfate ions $\left(\mathrm{Cl}^{-}\right.$, $\mathrm{NO}_{3}{ }^{-}$, and $\mathrm{SO}_{4}{ }^{2-}$, respectively) to a precision of $5 \%$. An Inductively Coupled Plasma-Atomic Emission Spectrometer (Jarrell Ash 955) was used to measure the mass concentration of the potassium ion $\left(\mathrm{K}^{+}\right)$to a precision of $4 \%$. Each of these measurements was accompanied by analysis of field blanks to correct for ambient signals. Further details on the Teflon filter analyses of aerosol compounds and the results obtained are given by Gao et al. [2003].

[8] The filters and $\mathrm{SO}_{2}$ measurements often required sampling times longer than it typically took the aircraft to cross the widths of individual smoke plumes $(\sim 1-2 \mathrm{~min})$. Therefore, when sampling plumes, we generally employed a "grab-bag" technique to obtain samples for the filters and $\mathrm{SO}_{2}$. The "grab-bag" consisted of a $2.5 \mathrm{~m}^{3}$ electrically conducting plastic (Velostat) bag that could be filled with a sample of smoke in $12 \mathrm{~s}$ when exposed to ram air. Samples in the grab-bag were drawn through filters for subsequent chemical analysis and mass determination of the aerosol. Various gas and aerosol instruments, such as particle size measurements normally used for real-time measurements, were configured so they could also analyze grab-bag samples. The grab-bag system had an aerosol 50\% cut-off diameter of about $4 \mu \mathrm{m}$ [Herring, 1994]; larger particles were lost in the inlet and on the walls of the grab bag. Nephelometric measurements indicated that aerosol mass in the grab-bag decreased by $\sim 15 \%$ during the period of the filter sampling, presumably due to losses to the surface of the bag. Therefore, measurements of aerosol mass given here that are based on grab-bag samples may be low by up to $\sim 15 \%$. Grab-bag samples of ambient air were generally followed by continuous sampling of the ambient air, allowing comparisons between the two sampling techniques.

[9] Measurements of $\mathrm{SO}_{2}$ were made on grab-bag samples using a Teco model $43 \mathrm{~S}$ pulsed-fluorescence analyzer (precision of $7 \%$, detection limit of $1.2 \mathrm{ppb}$ ). Calibration of this instrument, both in flight and on the ground, was carried out with commercial standard mixture (Scott-Marrin) of $180 \pm 9 \mathrm{ppb} \mathrm{SO}_{2}$ in ultra pure air. The instrument was zeroed using "pure" air $\left(\mathrm{SO}_{2}<1 \mathrm{ppb}\right)$.

[10] Evacuated electropolished stainless steel canisters were used to sample smoke plumes, or ambient air just upwind of the fires, using a stainless steel inlet that passed through the aircraft fuselage. The canisters were subsequently analyzed for hydrocarbons, halocarbons, dimethyl sulfide (DMS), and methyl nitrate $\left(\mathrm{CH}_{3} \mathrm{ONO}_{2}\right)$. The mixing ratios of species obtained in the ambient air were subtracted from the corresponding mixing ratios measured in the smoke samples to obtain excess mixing ratios. The canisters filled in $\sim 30 \mathrm{~s}$ at a nonlinear rate.

[11] For each whole air sample, mixing ratios of selected $\mathrm{C}_{2}-\mathrm{C}_{11}$ nonmethane hydrocarbons (NMHC), methyl chloride $\left(\mathrm{CH}_{3} \mathrm{Cl}\right)$, methyl iodide $\left(\mathrm{CH}_{3} \mathrm{I}\right)$, and methyl bromide $\left(\mathrm{CH}_{3} \mathrm{Br}\right)$ were determined by gas chromatography (GC) with flame ionization detection (FID) and electron capture 
detection (ECD). The precision of the NMHC and methyl halide measurements was $3 \%$, and the typical $\mathrm{NMHC}$ detection limit 3 pptv. Mixing ratios of $\mathrm{CO}_{2}$ (precision of $3 \%$ ), $\mathrm{CO}$ (precision of $5 \%$ ), and $\mathrm{CH}_{4}$ (precision of $0.1 \%$ ) in the canisters were determined using a second GC/FID. A detailed description of the analytical procedure for the whole air samples, including quantification of the measurement precision for individual compounds, is given by $\mathrm{Col}$ man et al. [2001].

[12] An Airborne Fourier Transform Infrared spectrometer (AFTIR) was deployed onboard with a separate and specially coated inlet that directed ram air through a Pyrex multipass cell with an exchange time of 4-5 s. AFTIR acquired the infrared spectrum of the cell contents every 0.83 s allowing water vapor $\left(\mathrm{H}_{2} \mathrm{O}\right), \mathrm{CO}_{2}, \mathrm{CO}$, and $\mathrm{CH}_{4}$ to be measured continuously. For the plume penetrations, the AFTIR was used to detain smoke samples for 2-3 min of signal averaging, which allowed measurements of most reactive and stable trace gases that were present above 520 ppbv. The gases were $\mathrm{H}_{2} \mathrm{O}, \mathrm{CO}_{2}, \mathrm{CO}$, nitric oxide (NO), nitrogen dioxide $\left(\mathrm{NO}_{2}\right), \mathrm{CH}_{4}$, ethene $\left(\mathrm{C}_{2} \mathrm{H}_{4}\right)$, acetylene $\left(\mathrm{C}_{2} \mathrm{H}_{2}\right)$, formaldehyde $(\mathrm{HCHO})$, methanol $\left(\mathrm{CH}_{3} \mathrm{OH}\right)$, acetic acid $\left(\mathrm{CH}_{3} \mathrm{COOH}\right)$, formic acid $(\mathrm{HCOOH})$, ammonia $\left(\mathrm{NH}_{3}\right)$, $\mathrm{O}_{3}$, and hydrogen cyanide $(\mathrm{HCN})$. This provided a rare capability to measure several important gases by two independent methods. The AFTIR technique and results are described in detail by Yokelson et al. [2003].

[13] The total concentrations of particles in the size range $0.003-3 \mu \mathrm{m}$ diameter were measured with a TSI $3025 \mathrm{~A}$ ultrafine condensation particle counter (precision of $10 \%$ ). A Particle Measuring Systems (PMS) passive cavity aerosol spectrometer probe (PCASP-100X) was also used for measuring particle size spectra. The PCASP-100X is an optical particle counter that was mounted on the wing of the aircraft. The sampling inlet was heated to dry the particles, so that measurements from the PCASP could be compared with those obtained on dried particles with other instruments inside the aircraft cabin. The PCASP-100X was regularly calibrated on the ground using polystyrene latex spheres of known sizes. A differential mobility particle sizer (DMPS) was used to measure aerosol size spectra from 0.01-0.6 $\mu \mathrm{m}$ diameter [Winklmayer et al., 1991]. Since this instrument requires a $2-4 \mathrm{~min}$ analysis time, it was fed from the grab bag.

\section{Definition and Calculation of Excess Molar Mixing Ratio, Normalized Excess Molar Emission Ratio, Emission Factor, and Combustion Efficiencies}

[14] The excess molar or volume mixing ratio, $\Delta \mathrm{X}$, of a species $\mathrm{X}$ in a smoke plume is defined as:

$$
\Delta \mathrm{X}=\mathrm{X}_{\text {plume }}-\mathrm{X}_{\text {ambient }}
$$

where, $X_{\text {plume }}$ and $X_{\text {ambient }}$ are the molar or volume mixing ratios of $\mathrm{X}$ in the smoke plume and in the ambient air, respectively.

[15] The normalized excess molar emission ratio of a species $\mathrm{X}, \mathrm{ER}(\mathrm{X})$, is the excess molar or volume mixing ratio of $\mathrm{X}$ divided by the excess molar or volume mixing ratio of a reference tracer (such as $\mathrm{CO}$ or $\mathrm{CO}_{2}$ ) measured close to a fire. For example, the normalized excess molar emission ratio of species $\mathrm{X}$ relative to $\mathrm{CO}$ is:

$$
\mathrm{ER}(\mathrm{X})=\frac{\Delta \mathrm{X}}{\Delta \mathrm{CO}}
$$

The normalized excess molar emission ratio can be obtained from the slope of the regression line between the excess mixing ratio of $X$ (e.g., excess values of $X$ in ppmv) and the excess mixing ratio of the reference tracer.

[16] Emission factors for gases and particles were calculated using the carbon mass balance method [Radke et al., 1988; Ward and Radke, 1993]. The underlying premise of this method is that all of the carbon combusted in a fire and released to the atmosphere is emitted into the smoke plume as $\mathrm{CO}_{2}, \mathrm{CO}, \mathrm{CH}_{4}$, nonmethane organic carbon (NMOC), and particulate carbon (PC). The emission factor (EF) of a species $\mathrm{X}$ is defined here as the ratio of the excess mass concentration $[\Delta \mathrm{X}]$ of $\mathrm{X}$ emitted by a fire to the excess mass concentration of total carbon, $[\Delta \mathrm{C}]$, emitted by the fire:

$\mathrm{EF}(\mathrm{X})=\frac{[\Delta \mathrm{X}]}{[\Delta \mathrm{C}]_{\mathrm{CO}_{2}}+[\Delta \mathrm{C}]_{\mathrm{CO}}+[\Delta \mathrm{C}]_{\mathrm{CH}_{4}}+[\Delta \mathrm{C}]_{\mathrm{NMOC}}+[\Delta \mathrm{C}]_{\mathrm{PC}}}$

The emission factor is expressed in units of grams of $\mathrm{X}$ emitted per kilogram of carbon burned. To convert this emission factor to units of grams of X emitted per kilogram of fuel burned, EF is multiplied by the mass fraction of carbon in the fuel. Typically, the carbon content of biomass fuels varies from 45 to $55 \%$ [Susott et al., 1996]. In this study, we assume that it is $50 \%$.

[17] The combustion efficiency (CE) is the molar ratio of excess carbon $(\mathrm{C})$ emitted as $\mathrm{CO}_{2}$ from a fire to the total excess carbon emitted [Ward and Hardy, 1991]:

$$
\mathrm{CE}=\frac{\Delta \mathrm{C}_{\mathrm{CO}_{2}}}{\Delta \mathrm{C}_{\mathrm{CO}_{2}}+\Delta \mathrm{C}_{\mathrm{CO}}+\Delta \mathrm{C}_{\mathrm{CH}_{4}}+\Delta \mathrm{C}_{\mathrm{NMOC}}+\Delta \mathrm{C}_{\mathrm{PC}}}
$$

Thus, CE is the molar fraction of fuel carbon emitted that is completely oxidized to $\mathrm{CO}_{2}$.

[18] Although CE is a useful quantity for fire models, it is often difficult to measure all of the individual carbon species in the emissions from a fire. Therefore, in this study we have chosen to use the modified combustion efficiency (MCE) as the principal quantity to describe the relative amounts of flaming and smoldering combustion [Ward and Hao, 1992; Ward and Radke, 1993], which is defined as:

$$
\mathrm{MCE}=\frac{\Delta \mathrm{C}_{\mathrm{CO}_{2}}}{\Delta \mathrm{C}_{\mathrm{CO}_{2}}+\Delta \mathrm{C}_{\mathrm{CO}}}
$$

Since $\mathrm{CH}_{4}$, NMOC and PC are emitted in relatively small quantities compared to $\mathrm{CO}_{2}$ and $\mathrm{CO}$, the difference between $\mathrm{CE}$ and MCE is typically only a few percent.

[19] Both CE and MCE are useful as indicators of the relative amounts of flaming and smoldering combustion that generate emissions. In laboratory studies, Yokelson et al. [1996] found that pure flaming combustion has an MCE near 0.99 and pure smoldering combustion an MCE of $\sim 0.8$. Therefore, an MCE $<0.9$ suggests $>50 \%$ smoldering combustion, and an MCE $>0.9$ suggests $>50 \%$ flaming 
combustion. In this study, the average MCE measured independently by the AFTIR (0.94) and the canister sampling (0.94) both show that the savanna fires sampled were often dominated by flaming combustion.

\section{Vegetative Types and Sampling of Smoke}

[20] The nature of the vegetative fuel plays an important role in determining emissions from biomass fires [e.g., Ward and Hardy, 1991]. We report here on measurements obtained in the smoke from 10 fires covering a variety of vegetation types in several regions of southern Africa (Table 1): four fires in South Africa, two in Zambia, one in Mozambique, and three on the Botswana/South Africa border. Vegetation types varied from lowvelds and highvelds in South Africa, to dambo and miombo woodlands in Zambia, to east African coastal mosaic in Mozambique. The lowveld fires were located in and around the Kruger National Park in South Africa. Vegetation in the lowvelds varied from south Zambezian undifferentiated woodland to Tongaland-Pondoland bushland [White, 1981, 1983]. The bushveld fires were located on the Botswana/South Africa border, in a Zambezian vegetation zone that transitions from undifferentiated woodland to Acacia deciduous bushland and wooded grassland. The miombo woodland fires in Zambia were in a Zambezian woodland vegetation zone dominated by species of Brachystegia and related genera. The dambo grassland fire in Zambia was in a seasonally flooded region covered with a medium-dense, uniform grass mat. The Mozambique fire was located in a transition zone between miombo woodland dominated by Brachystegia and a Zanzibar-Inhambane east African coastal mosaic of woodland habitats [White, 1981, 1983].

[21] More than 60 penetrations were made through the smoke plumes of the 10 fires. However, to determine emission factors, we use only the results for smoke samples less than a few minutes old acquired directly (typically $\sim 500 \mathrm{~m}$ ) above the fires, which we term "initial" smoke. Canisters were filled and grab-bag samples acquired during 16 penetrations of initial smoke.

\section{Results and Discussion}

[22] In this section we present emission ratios and emission factors for biomass burning in southern Africa of 50 gaseous and particulate species, including $\mathrm{CO}_{2}, \mathrm{CO}, \mathrm{NO}_{\mathrm{x}}$, $\mathrm{SO}_{2}$, oxygenates, hydrocarbons, halocarbons, ionic aerosols, and carbonaceous aerosols. These emissions affect the atmosphere in several important ways: greenhouse warming, the oxidizing capacity and acidity of the troposphere, stratospheric ozone depletion, and light scattering and absorption. Although much of the $\mathrm{CO}_{2}$ released in savanna fires is sequestered as vegetation grows back, this is not the case for the greenhouse gas $\mathrm{CH}_{4}$. Furthermore, $\mathrm{CO}$ released from fires is oxidized to $\mathrm{CO}_{2}$ through reacting with $\mathrm{OH}$, thus depleting the main sink for $\mathrm{CH}_{4}$ and lengthening its lifetime. Thus, $\mathrm{CO}$ released from biomass burning has indirect effects on global warming. Emissions of nitrogen oxides, organic compounds, and $\mathrm{CO}$ from biomass burning result in the formation of $\mathrm{O}_{3}$, another important greenhouse gas.

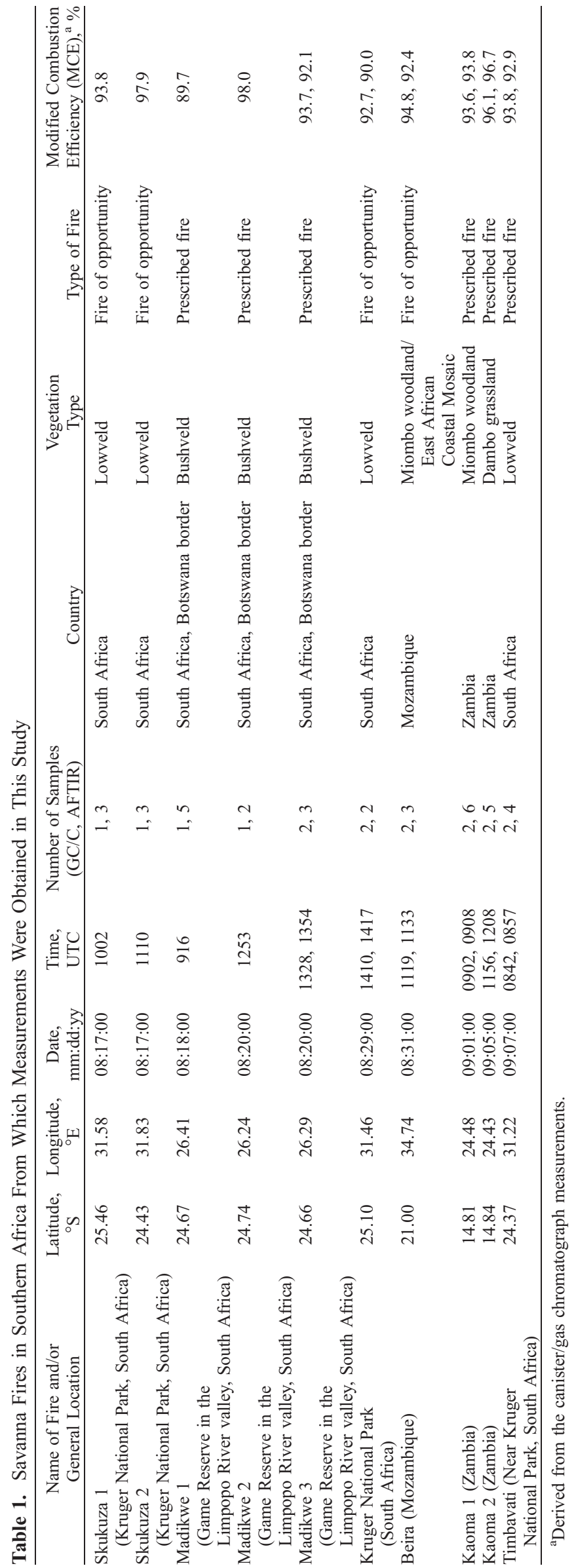


[23] We report here emission ratios and emission factors for precursors of the primary oxidants in the atmosphere, namely, $\mathrm{OH}$ and $\mathrm{O}_{3}$. Photolysis of $\mathrm{O}_{3}$ in the presence of water vapor will lead to the formation of $\mathrm{OH}$. Photolysis of formaldehyde released from biomass fires will produce $\mathrm{OH}$ and lead to $\mathrm{O}_{3}$. The oxidants produced in aged smoke will eventually be depleted by reactions with the $\mathrm{CO}$ and $\mathrm{CH}_{4}$ released in the fires. Also given here are emission ratios and emission factors for halocarbons, which can eventually serve as sources for chlorine or bromine in the stratosphere where they will catalyze stratospheric $\mathrm{O}_{3}$ depletion.

[24] Emission ratios and emission factors are given for aerosols that scatter and/or absorb solar radiation. Inorganic and organic aerosols scatter solar radiation, reducing the downwelling flux available for photochemistry and warming of the Earth's surface. Black carbon absorbs solar radiation, which warms layers of the atmosphere, creating vertical stability below them that can confine pollutants near the surface. Ions, such as sulfate and nitrate, either released from fires or formed through the oxidation of $\mathrm{SO}_{2}$ and $\mathrm{NO}_{\mathrm{x}}$, can be removed from the atmosphere by either dry or wet deposition, thereby acidifying precipitation and soils. Acetic and formic acid, released from fires or formed through the oxidation of hydrocarbons, will also affect the $\mathrm{pH}$ of precipitation and soils. Emission of positive ions, such as $\mathrm{K}^{+}$, and the formation of $\mathrm{NH}_{4}^{+}$from $\mathrm{NH}_{3}$ released from biomass fires, can partly neutralize these acids.

[25] It should be emphasized that the emission ratios and emission factors given here are based on measurements made in smoke just above the fires (i.e., initial smoke). Many of the emissions undergo transformations as the smoke ages, as discussed by Hobbs et al. [2003].

[26] It is beyond the scope of this paper to discuss all aspects of the large data set reported here. Instead we will focus on those species that have not been previously estimated or measured, and those species for which the emission ratios and emission factors derived from our measurements differ significantly from those reported in earlier studies. (We define "significant" as a statistical confidence level $\geq 95 \%$.) It should also be noted that many more species were measured than are reported here. In this paper, a species was considered to be emitted from a fire only if the correlation coefficient $\left(r^{2}\right)$ for the excess mixing ratio of that species against the excess mixing ratio of $\mathrm{CO}$ (or $\mathrm{CO}_{2}$ ) was $\geq 0.5$.

\subsection{Emission Ratios}

[27] The excess molar mixing ratio of each species was regressed against the excess molar mixing ratio of $\mathrm{CO}$ or $\mathrm{CO}_{2}$ to obtain the emission ratio of that species. The slope of the regression line gives the molar emission ratio (hereafter abbreviated to "emission ratio") of the species with respect to the reference tracer $\left(\mathrm{CO}\right.$ or $\left.\mathrm{CO}_{2}\right)$. Since $\mathrm{NO}_{\mathrm{x}}$, $\mathrm{SO}_{2}$, and $\mathrm{CO}_{2}$ are mainly emitted in flaming combustion, excess values of $\mathrm{NO}_{\mathrm{x}}$ and $\mathrm{SO}_{2}$ were regressed against excess $\mathrm{CO}_{2}$. Other compounds are mainly emitted with $\mathrm{CO}$ during smoldering combustion, so their excess mixing ratios were regressed against excess $\mathrm{CO}$.

[28] Figure 1 shows the excess mixing ratios of several species plotted against excess mixing ratios of $\mathrm{CO}\left(\right.$ or $\left.\mathrm{CO}_{2}\right)$. Slopes and correlation coefficients for these and all the other species we measured are listed in Table 2 (for the canister samples) and in Table 3 (for the AFTIR samples). For emission ratios obtained from the gas chromatography measurements (Table 2), an average emission ratio for a given species was derived using the sixteen canister samples from the 10 fires. For the AFTIR measurements (Table 3), there were often several measurements close to the fire in each of the smoke plumes. For these cases, we give an average emission ratio for each measured species for each fire. The average emission ratios of $\mathrm{CO}, \mathrm{CH}_{4}$, and acetylene in Table 2 are not significantly different from the corresponding values listed in Table 3 . However, the average emission ratio for ethene determined from the AFTIR is about $50 \%$ greater than that determined from gas chromatography. In section 6 of this paper we compare and discuss measurements obtained by gas chromatography with those obtained by AFTIR. Emission ratios are not given here for $\mathrm{O}_{3}$ since, although $\mathrm{O}_{3}$ develops downwind in smoke plumes, it is not emitted directly from a fire. The time evolution of $\mathrm{O}_{3}$ in one of the smoke plumes we studied is described by Hobbs et al. [2003].

[29] For comparison with our measurements, we also show in Table 2 the emission ratios for smoke from savanna fires in southern Africa and agricultural fires in Brazil reported by Blake et al. [1996], and for smoke from grass, cerrado and forest fires in Brazil given by Ferek et al. [1998]. The analysis techniques used in these two studies were similar to those we used in Africa. The sampling by Blake et al. [1996] in Africa was conducted in SeptemberOctober 1992, similar to the August-September period of SAFARI 2000. However, most of the samples collected by Blake et al. were of aged smoke, whereas, the measurements reported here and those of Ferek et al. are for initial smoke.

[30] Blake et al. reported emission ratios for $\mathrm{CH}_{4}$ with respect to $\mathrm{CO}$ of $0.078 \pm 0.004$ and $0.094 \pm 0.013$ for southern Africa and Brazil, respectively. For Brazil, Ferek et al. report a $\mathrm{CH}_{4}$ emission ratio of 0.12 . Our emission ratios for $\mathrm{CH}_{4}$ in southern Africa are $0.039 \pm 0.003$ for samples collected in canisters and $0.053 \pm 0.012$ from the AFTIR measurements. It appears from the average of these measurements that the $\mathrm{CH}_{4}$ emission ratio with respect to $\mathrm{CO}$ from biomass burning in Brazil $(0.11 \pm 0.02)$ may be greater than that for savanna burning in southern Africa $(0.057 \pm$ 0.013). This could be due to high $\mathrm{CH}_{4}$ emissions for downed woody material [Bertschi et al., 2003].

[31] We found a stronger correlation between excess $\mathrm{CH}_{3} \mathrm{Br}$ and excess $\mathrm{CO}\left(r^{2}=0.69\right)$ than between excess $\mathrm{CH}_{3} \mathrm{I}$ and excess $\mathrm{CO}\left(r^{2}=0.50\right)$ (Table 2). The emission ratios for $\mathrm{CH}_{3} \mathrm{Br}, \mathrm{CH}_{3} \mathrm{Cl}$ and $\mathrm{CH}_{3} \mathrm{I}$ reported here are $10-$ $40 \%$ lower than those reported by Blake et al. [1996] for African biomass fires, and 30-66\% lower than those reported by Blake et al. for Brazilian fires. Mano and Andreae [1994] estimated that $\mathrm{CH}_{3} \mathrm{Br}$ emissions from biomass burning worldwide range from 10 to $50 \mathrm{Gg}$ per year, which is comparable to that from oceans and pesticide use. Their value was obtained using a methyl bromide-to-methyl chloride emission ratio of $6 \times 10^{-3}$ to $9 \times 10^{-3}$. Based on the measurements reported here for savanna burning in southern Africa, the emission ratio of methyl bromide with respect to methyl chloride is $(7.5 \pm 0.6) \times 10^{-3}$ (Figure 2), which lies within the range used by Mano and Andreae. 

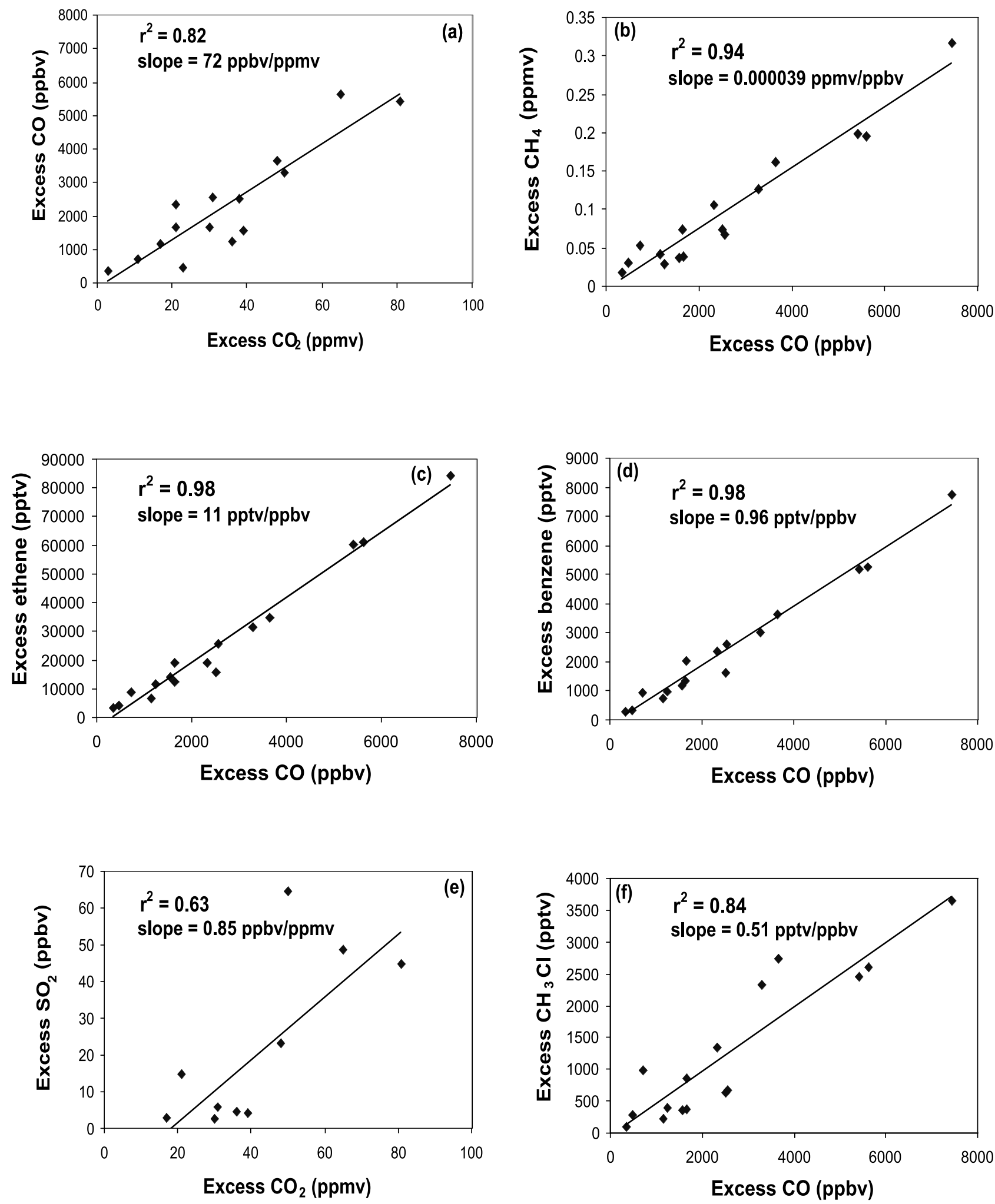

Figure 1. Excess mixing ratios of selected trace gases (measured in canisters) versus excess mixing ratios of $\mathrm{CO}_{2}$ or $\mathrm{CO}$ in the smoke from savanna fires in southern Africa. The correlation coefficient is given by $r^{2}$.

[32] S. Meinardi et al. (Dimethyl disulfide and dimethyl sulfide emissions from biomass burning, submitted to Geophysical Research Letters, 2002) detected emissions of dimethyl sulfide $\left(\mathrm{CH}_{3} \mathrm{SCH}_{3}\right.$ or DMS) from bush fires in
Australia. Their molar emission ratio of DMS to $\mathrm{CO}$ was $6.3 \times 10^{-6}$. The mixing ratios of DMS in southern Africa smoke plumes are strongly correlated with $\mathrm{CO}$ (Table 2 and Figure 3). This confirms that biomass burning is a source of 


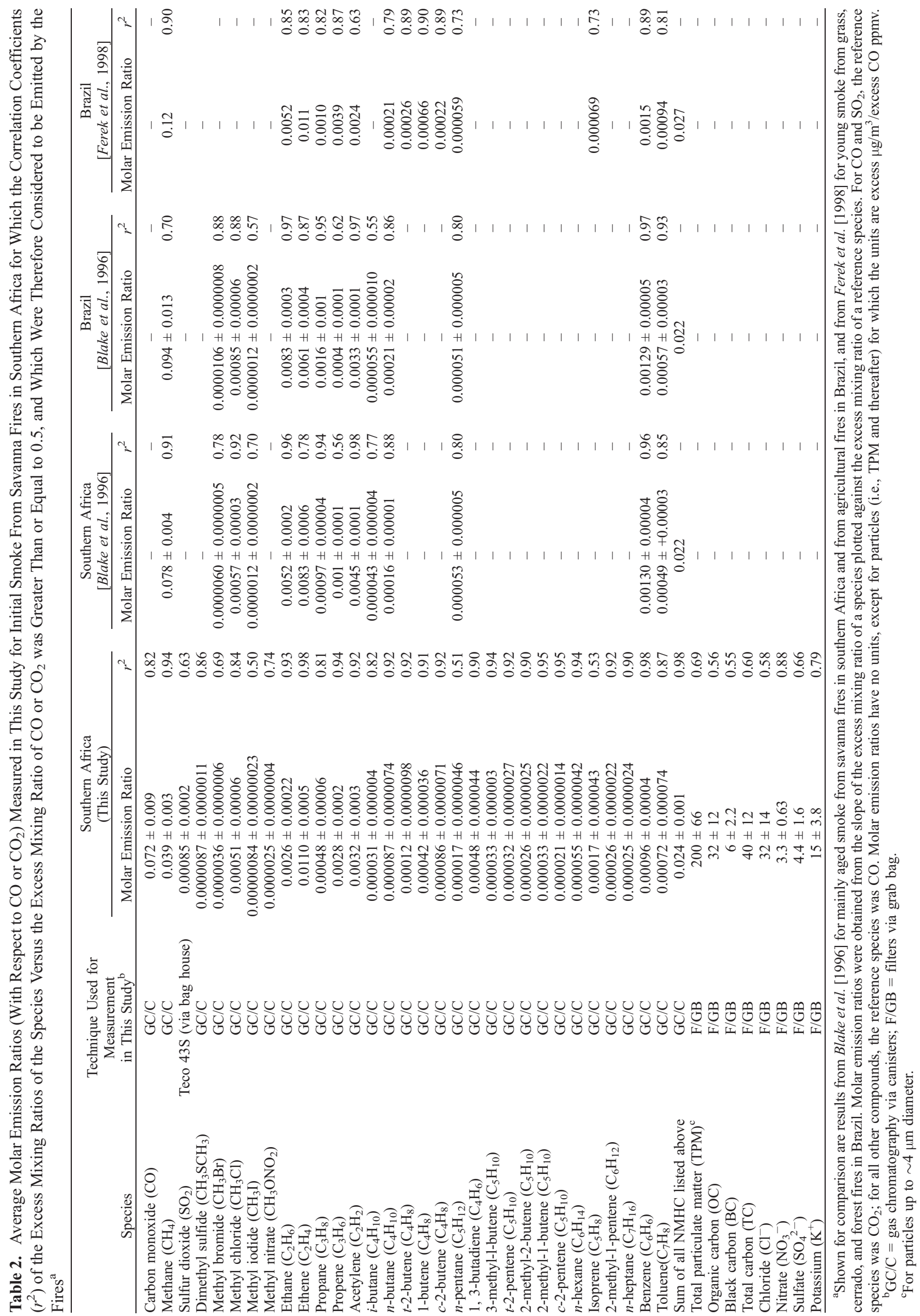


Table 3. As for Table 2 But for Smoke From Some of the Individual Savanna Fires Sampled by AFTIR in Southern Africa in This Study ${ }^{\mathrm{a}}$

\begin{tabular}{|c|c|c|c|c|c|c|c|c|c|}
\hline Species & $\begin{array}{c}\text { Skukuza } \\
1,2\end{array}$ & $\begin{array}{c}\text { Madikwe } \\
1\end{array}$ & $\begin{array}{l}\text { Madikwe } \\
2,3\end{array}$ & $\begin{array}{c}\text { Kruger } \\
\text { National Park }\end{array}$ & Beira & $\begin{array}{c}\text { Kaoma } \\
1\end{array}$ & $\begin{array}{c}\text { Kaoma } \\
2\end{array}$ & Timbavati & $\begin{array}{c}\text { Average } \pm \text { Standard Deviation } \\
\text { From This Study }\end{array}$ \\
\hline Carbon monoxide $(\mathrm{CO}) / \mathrm{CO}_{2}$ & 0.078 & 0.059 & 0.046 & 0.073 & 0.099 & 0.063 & 0.026 & 0.069 & $0.064 \pm 0.022$ \\
\hline Nitric oxide $(\mathrm{NO}) / \mathrm{CO}_{2}$ & 0.0019 & 0.0019 & 0.001 & 0.0011 & - & 0.0010 & 0.0009 & 0.0008 & $0.0011 \pm 0.0004$ \\
\hline Nitrogen dioxide $\left(\mathrm{NO}_{2}\right) / \mathrm{CO}_{2}$ & 0.0016 & 0.0020 & 0.0022 & 0.0019 & 0.0030 & 0.0020 & 0.0011 & 0.0018 & $0.0020 \pm 0.0005$ \\
\hline Methane $\left(\mathrm{CH}_{4}\right) / \mathrm{CO}$ & 0.059 & 0.054 & 0.048 & 0.070 & 0.061 & 0.036 & 0.038 & 0.059 & $0.053 \pm 0.012$ \\
\hline Ethene $\left(\mathrm{C}_{2} \mathrm{H}_{4}\right) / \mathrm{CO}$ & 0.019 & 0.015 & 0.020 & 0.016 & 0.016 & 0.012 & 0.023 & 0.016 & $0.017 \pm 0.003$ \\
\hline Acetylene $\left(\mathrm{C}_{2} \mathrm{H}_{2}\right) / \mathrm{CO}$ & 0.0033 & 0.0037 & 0.0054 & 0.0043 & 0.0037 & 0.0037 & 0.0072 & 0.0034 & $0.0043 \pm 0.0013$ \\
\hline Methanol $\left(\mathrm{CH}_{3} \mathrm{OH}\right) / \mathrm{CO}$ & 0.014 & 0.016 & 0.015 & 0.020 & 0.014 & 0.013 & 0.0093 & 0.015 & $0.015 \pm 0.003$ \\
\hline Acetic acid $\left(\mathrm{CH}_{3} \mathrm{CO}_{2} \mathrm{H}\right) / \mathrm{CO}$ & 0.019 & 0.017 & 0.017 & 0.017 & 0.016 & 0.015 & 0.013 & 0.015 & $0.016 \pm 0.002$ \\
\hline Formic acid $\left(\mathrm{HCO}_{2} \mathrm{H}\right) / \mathrm{CO}$ & 0.0021 & 0.0066 & 0.0087 & 0.0054 & 0.0045 & 0.0051 & 0.0087 & 0.0064 & $0.0059 \pm 0.0022$ \\
\hline Ammonia $\left(\mathrm{NH}_{3}\right) / \mathrm{CO}$ & 0.0076 & 0.0081 & 0.012 & 0.0027 & - & 0.0097 & - & 0.0016 & $0.0070 \pm 0.0046$ \\
\hline Hydrogen cyanide $(\mathrm{HCN}) / \mathrm{CO}$ & 0.0094 & 0.011 & 0.013 & 0.0059 & 0.0056 & 0.056 & 0.011 & 0.0072 & $0.0085 \pm 0.0029$ \\
\hline
\end{tabular}

${ }^{\mathrm{a}}$ See Table 1 for information on each fire.

DMS. Using our value for the molar emission ratio of DMS with respect to $\mathrm{CO}\left[(8.7 \pm 1.1) \times 10^{-6}\right]$, together with an estimate for the annual emission of $\mathrm{CO}$ worldwide from savanna and grassland burning (206 $\mathrm{Tg} \mathrm{yr}^{-1}$ [Andreae and Merlet, 2001]), yields an annual flux of DMS from savanna and grassland burning of $2.9 \pm 0.4 \mathrm{Gg} \mathrm{yr}^{-1}$. For comparison, the annual flux of DMS from the world's oceans is $30-50 \mathrm{Tg}$ $\mathrm{yr}^{-1}$ [Seinfeld and Pandis, 1998]. However, there are large uncertainties associated with this type of extrapolation, in which a small number of data points from a specific region and season are used as a surrogate for DMS emissions from global savanna and grassland burning throughout the year. Also, there are significant uncertainties in the global $\mathrm{CO}$ emission estimates, which are known to within only about $\pm 50 \%$ [Blake et al., 1996].

[33] Although small in relation to marine sources, DMS from biomass burning could be an important source of sulfur in nonindustrial, continental interiors, even though direct emissions of sulfur as $\mathrm{SO}_{2}$ from biomass burning $\left(0.43 \pm 0.30 \mathrm{~g} \mathrm{~kg}^{-1}\right.$ for savanna burning in southern Africa) dominates over that of DMS $\left(0.0013 \pm 0.0011 \mathrm{~g} \mathrm{~kg}^{-1}\right)$. Oxidation of DMS by $\mathrm{OH}$ leads to the formation of $\mathrm{SO}_{2}$. The lifetime of DMS with respect to $\mathrm{OH}$ oxidation is $\sim 2$ days [Warneck, 2000]. On the other hand, the lifetime of $\mathrm{SO}_{2}$ with respect to removal by dry deposition is only $\sim 1$ day [Seinfeld and Pandis, 1998]. Therefore, DMS will be transported over larger distances after which, following oxidation by $\mathrm{OH}$, it will serve as a source of $\mathrm{SO}_{2}$.

[34] The AFTIR aboard the Convair-580 in SAFARI 2000 provided the first quantitative measurements of oxygenated organic compounds in smoke from savanna fires (Table 3). The emission ratios of these compounds show that 3 of the top 5 organic compounds emitted by savanna fires are oxygenated. These compounds are discussed further in section 5.2 of this paper and by Yokelson et al. [2003].

[35] Many other species measured in this study show potentially interesting results, but are not included in our tabulations or discussion because they did not satisfy our criteria for being emitted from the biomass fires (i.e., a

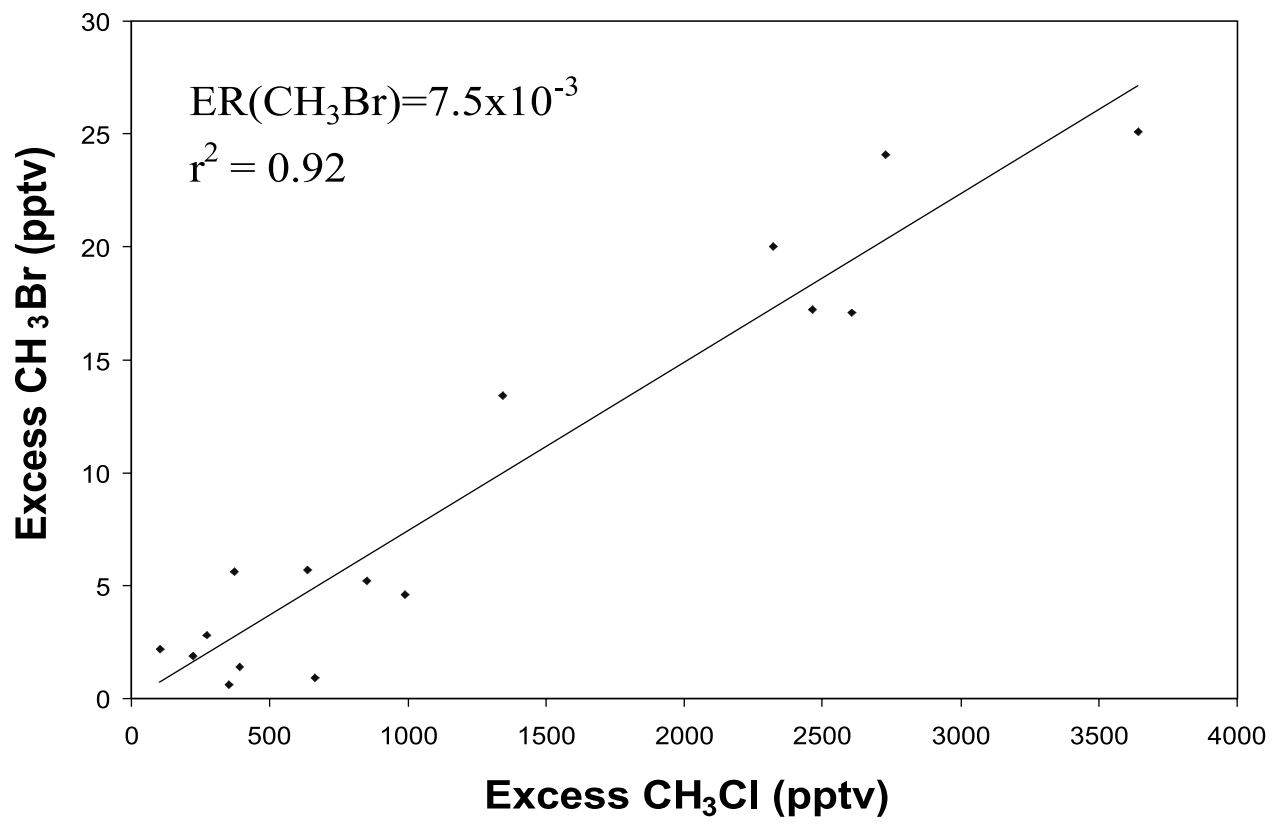

Figure 2. Excess mixing ratio of methyl bromide versus excess mixing ratio of methyl chloride. The molar emission ratio (ER) for methyl bromide with respect to methyl chloride obtained from the slope of the plot is shown. The correlation coefficient is given by $r^{2}$. 


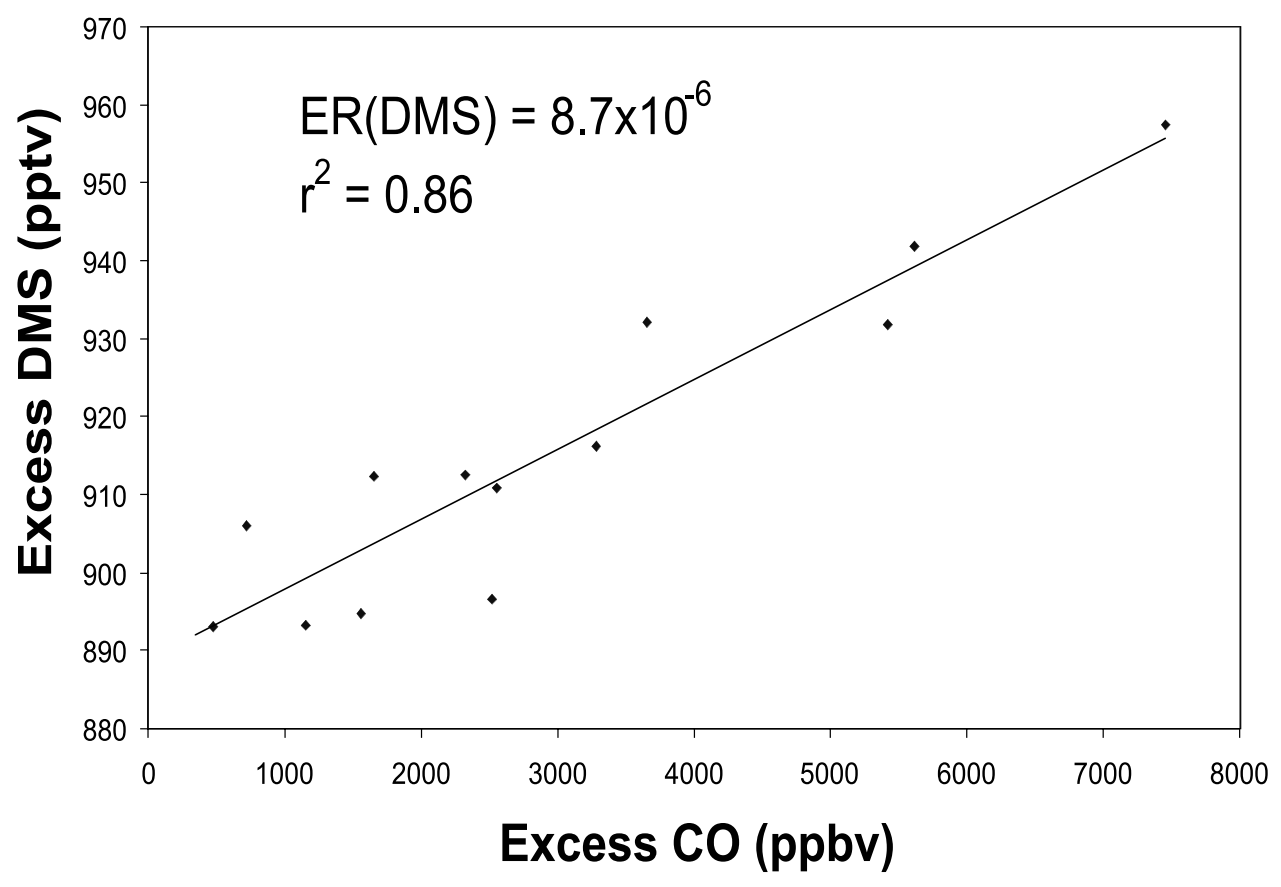

Figure 3. Excess mixing ratios of DMS versus excess mixing ratios of $\mathrm{CO}$. The molar emission ratio (ER) for DMS with respect to $\mathrm{CO}$ obtained from the slope of the plot is shown. The correlation coefficient is given by $r^{2}$.

correlation coefficient $\geq 0.5$ for the excess mixing ratio of the species against the excess mixing ratio of $\mathrm{CO}$ or $\mathrm{CO}_{2}$ ). For example, based on our measurements, the emission ratio of $i$-pentane with respect to excess $\mathrm{CO}$ in the smoke was about a factor of 5 below that reported by Ferek et al. [1998]. However, the correlation coefficient for the excess mixing ratio of $i$-pentane against the excess mixing ratio of CO was 0.43 .

\subsection{Emission Factors}

[36] All of the emission factors (EF) reported here are based on airborne measurements made in smoke directly over, or within a few kilometers of the fire, that is, in initial smoke. As smoke ages, species within it are removed and others are generated by chemical and physical processes. Various effects of the aging of smoke are discussed by Hobbs et al. [2003], Yokelson et al. [2003], Magi and Hobbs [2003], Gao et al. [2003], Li et al. [2003], and Pósfai et al. [2003].

[37] As mentioned previously, if the correlation coefficient $\left(r^{2}\right)$ for the excess molar mixing ratio of a species against the excess molar mixing ratio of $\mathrm{CO}$ (or $\mathrm{CO}_{2}$ ) was $\geq 0.5$, biomass burning was considered to be a significant source of that species. The emission factors for all such species from the present study are given in Table 4.

[38] Figure 4 shows the EF of several gases plotted against the modified combustion efficiency (MCE) based on gas chromatography analysis of the sixteen canister samples obtained in the 10 fires reported here. The slope of the regression of EF versus MCE indicates the importance of the combustion processes (flaming or smoldering) in determining the emission factor: the steeper the slope, the greater the dependence on the combustion process. A positive slope indicates that emission of the species is favored by flaming combustion (Figure 4a), and a negative slope that it is favored by smoldering combustion (Figures $4 \mathrm{~b}-4 \mathrm{f})$. The effectiveness of the MCE as an independent variable for determining $\mathrm{EF}$ is given by the correlation coefficient between EF and MCE. For species that have a high correlation coefficient between $\mathrm{EF}$ and MCE, measurements of $\mathrm{CO}$ and $\mathrm{CO}_{2}$ alone (which together determine the MCE) may be used to estimate EF. Similar plots to Figure 4, but for the oxygenated compounds measured by the AFTIR, are given by Yokelson et al. [2003].

[39] Table 5 lists slopes, intercepts, and correlation coefficients for the emission factors regressed against MCE for various species collected in the stainless steel canisters and by AFTIR. For many of the species listed in Table 5 (except $\mathrm{CO}_{2}$ of course, see equation (5)), the emission factor decreases with increasing MCE (indicated by negative slopes in Table 5). This shows that these species are preferentially released during smoldering combustion. However, for those species whose emission factors are weakly correlated with MCE (indicated by low values of $r^{2}$ in Table 5), the emissions are not strongly dependent on the combustion process. Our results for $\mathrm{SO}_{2}$ show a negative slope for $\mathrm{EF}$ versus $\mathrm{MCE}$ and a reasonably high $r^{2}$ value $(0.56$, Table 5$)$, even though laboratory studies indicate that $\mathrm{SO}_{2}$ is preferentially released in flaming combustion [Crutzen and Andreae, 1990; Yokelson et al., 1996]. This could result from fires with low values of the MCE occurring by chance in fuels with high sulfur content.

[40] Figure 5 compares the emission factors of $\mathrm{CO}_{2}, \mathrm{CO}$, $\mathrm{CH}_{4}$, and NMOC reported here for the burning of savanna in southern Africa with those reported by Ferek et al. [1998] for the burning of grassland in Brazil, and with the global compilation of emission factors for savanna burning by Andreae and Merlet [2001]. Taking into account the stand- 


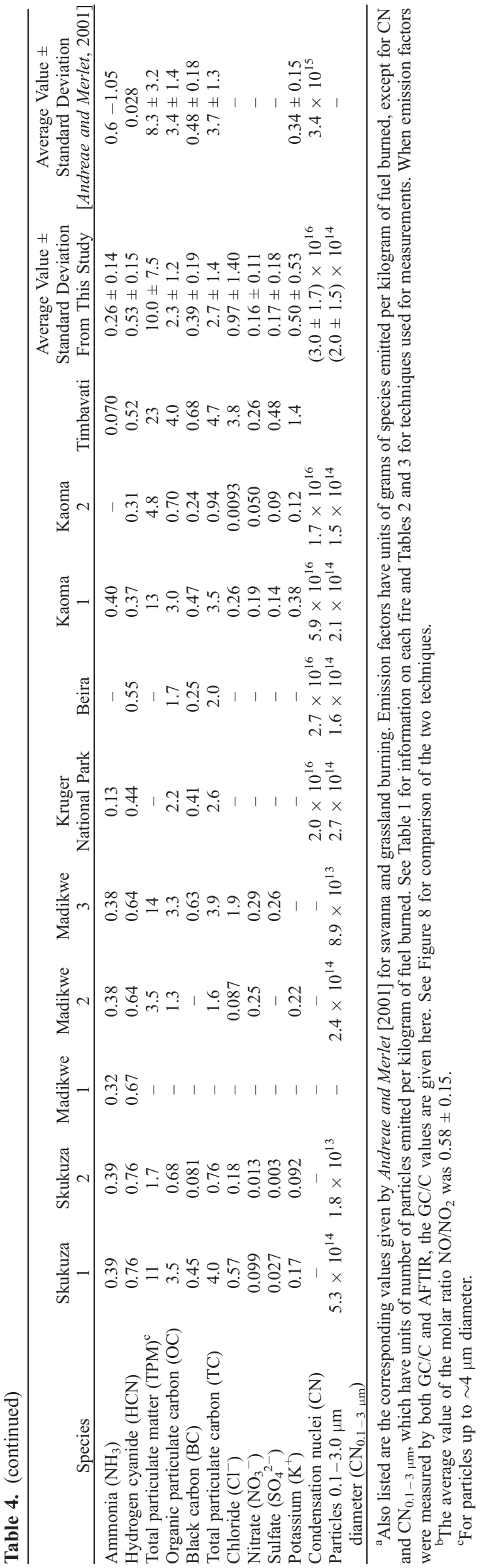

ard deviations of the measurements, the mean emission factors for $\mathrm{CO}_{2}, \mathrm{CO}, \mathrm{CH}_{4}$, and $\mathrm{NMHC}$ provided by these three studies are similar.

[41] Figure 6 compares the emission factors reported here for total particulate matter, total particulate carbon, organic carbon, and black carbon with those given by Ferek et al. [1998] for the burning of grassland in Brazil and with the compilation by Andreae and Merlet [2001]. In view of the standard deviations of the measurements, the mean emission factors for total particulate matter, total carbon, organic carbon, and black carbon given in these three studies are similar.

[42] The single-scattering albedo of smoke emitted from biomass fires depends on the ratio of organic carbon to black carbon [Mazurek et al., 1991]. The ratio of the emission factors of black carbon to organic carbon in this study is $0.17 \pm 0.12$. The corresponding value given by Andreae and Merlet [2001] for savanna and grassland burning is $0.14 \pm 0.08$.

[43] The emission factors of several compounds reported here (Table 4 and Figure 7) differ from those reported by Andreae and Merlet [2001]. For example, the average emission factor for $\mathrm{NH}_{3}$ measured in this study is $0.26 \pm$ $0.15 \mathrm{~g} \mathrm{~kg}^{-1}$ compared to $0.6-1.5 \mathrm{~g} \mathrm{~kg}^{-1}$ given by Andreae and Merlet. Multiplying the average $\mathrm{NH}_{3}$ emission factor for savanna fires in southern Africa given here by an estimate for savanna burned in Africa $\left(1600 \mathrm{Tg} \mathrm{yr}^{-1}\right.$ [Hao and Liu, 1994]) yields $0.34 \pm 0.27 \mathrm{Tg} \mathrm{yr}^{-1}$ of $\mathrm{NH}_{3}$ emitted by African savanna fires. Since the emission of ammonia from all sources worldwide is believed to be $\sim 55$ $\mathrm{Tg}_{\mathrm{yr}}{ }^{-1}$ [Seinfeld and Pandis, 1998], savanna burning in Africa makes only a small contribution to global $\mathrm{NH}_{3}$ emissions. Boreal forest fires have a large emission factor for $\mathrm{NH}_{3}$ and may produce more total $\mathrm{NH}_{3}$ emissions [Goode et al., 2000].

[44] As mentioned earlier, AFTIR samples obtained in this study showed that oxygenated organic compounds were a major component of smoke from young savanna fires. On a mass basis the oxygenated emissions dominate the organic emissions. The oxygenates have important effects on chemical reactions in a smoke plume, as described by Mason et al. [2001]. On a mass basis acetic acid is the major initial organic emission $(\mathrm{EF}=2.4 \pm 0.9 \mathrm{~g} / \mathrm{kg})$, and its concentration rapidly increases downwind [Hobbs et al., 2003; Yokelson et al., 2003]. Methanol and formaldehyde are the other two major oxygenates emitted by these fires. Methanol is a source of $\mathrm{HO}_{2}$ and $\mathrm{HCHO}$ in the atmosphere. The average emission factor for the direct emission of $\mathrm{HCHO}$ given here is $1.1 \pm 0.38 \mathrm{~g} \mathrm{~kg}^{-1}$ (Table 4), compared to $0.26-0.44 \mathrm{~g} \mathrm{~kg}^{-1}$ given by Andreae and Merlet [2001]. Multiplying our average HCHO emission factor for savanna burning by the estimate of $1600 \mathrm{Tg} \mathrm{yr}^{-1}$ for savanna burned in Africa, yields $\sim 1.8 \pm 0.62 \mathrm{Tg} \mathrm{yr}^{-1}$ of $\mathrm{HCHO}$ emitted from savanna fires in Africa. Photolysis of $\mathrm{HCHO}$ produces $\mathrm{HO}_{2}$, which leads to conversion of $\mathrm{NO}$ to $\mathrm{NO}_{2}$ and subsequent ozone formation. Therefore, $\mathrm{HCHO}$ emissions from savanna burning may lead to increased initial ozone formation rates [Yokelson et al., 1999]. The oxygenated organic compounds were strongly affected by cloud processing [Yokelson et al., 2003].

[45] Our average emission factor for $\mathrm{HCN}$ is $0.53 \pm 0.15$ $\mathrm{g} \mathrm{kg}^{-1}$ (Table 4), compared to $0.025-0.03 \mathrm{~g} \mathrm{~kg}^{-1}$ given by 

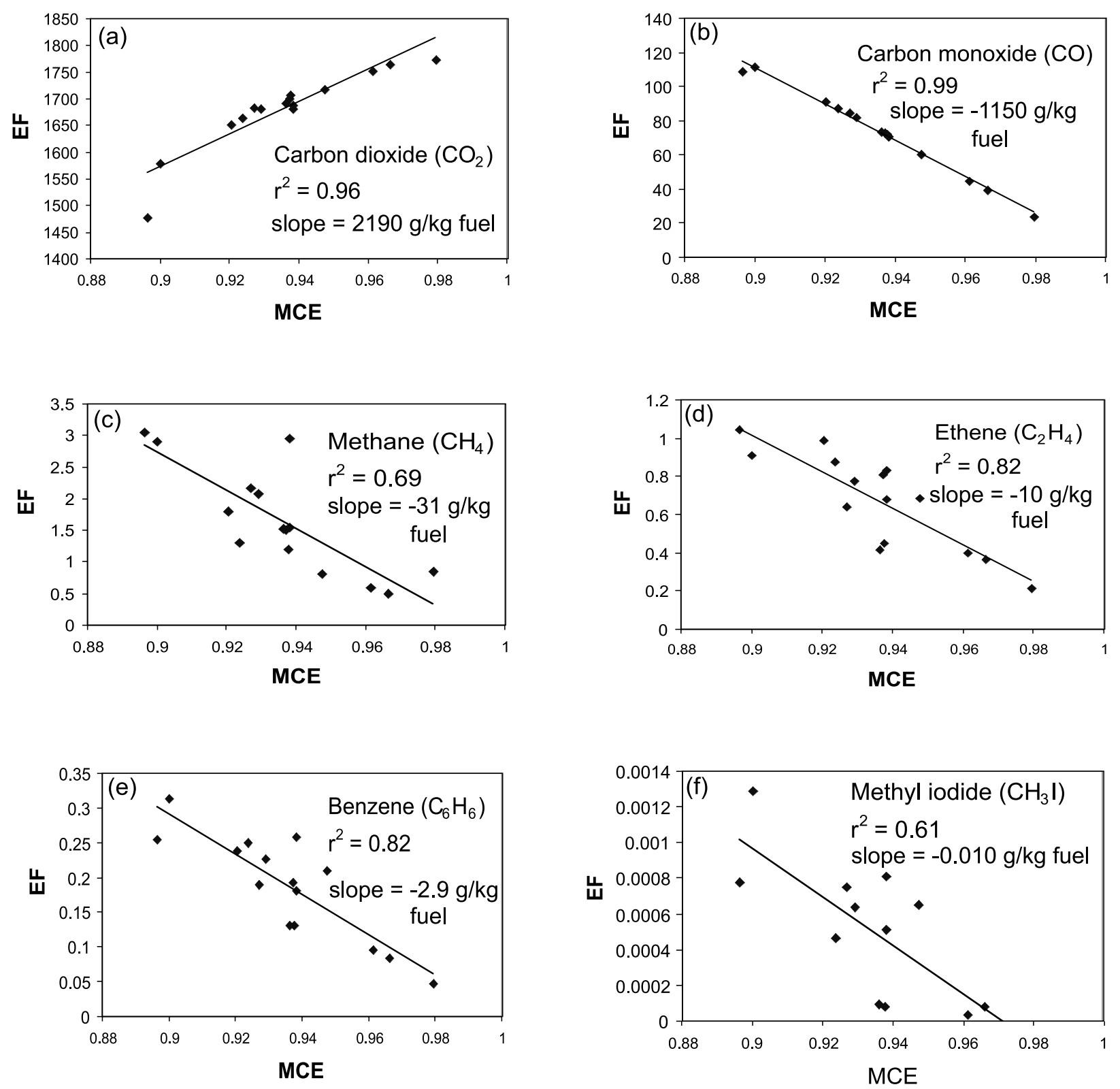

Figure 4. Emission factors (grams of species emitted per kilogram of fuel burned) versus modified combustion efficiency (MCE) for various trace gases in each of sixteen canister samples. The correlation coefficient is given by $r^{2}$.

Andreae and Merlet [2001]. Since the major global source for $\mathrm{HCN}$ is biomass burning, and since this species can be monitored from space, $\mathrm{HCN}$ has been proposed as a tracer for biomass burning [Li et al., 2000]. The abundance of $\mathrm{HCN}$ emitted by African savanna fires lends support to this proposal. It should be noted that $\mathrm{HCN}$ can interfere with $\mathrm{NO}_{\mathrm{y}}$ measurements [Kliner et al., 1997].

[46] The emission factor for aerosols (i.e., Aitken nuclei or condensation nuclei [CN]) given by Andreae and Merlet [2001], namely $3.4 \times 10^{15}$ particles per kilogram of fuel burned, is based on laboratory measurements. Taking into account the uncertainty in the measurements, our $\mathrm{CN}$ emission factor for savanna burning in southern Africa is $\sim 3-14$ times greater than the value given by Andreae and Merlet (Table 4 and Figure 7). Multiplying our average CN emission factor, $(3.0 \pm 1.7) \times 10^{16}$ particles per kilogram of fuel burned, by Hao and Liu's estimate of $1600 \mathrm{Tg} \mathrm{yr}^{-1}$ for savanna burned in Africa, yields $2 \times 10^{28}$ to $8 \times 10^{28} \mathrm{CN}$ emitted per year from African savanna fires. This estimate is about an order of magnitude greater than an earlier estimate by Le Canut et al. [1996] of $\sim 3 \times 10^{27}$ to $8 \times 10^{27}$ particles emitted per year worldwide by savanna fires. Since $\sim 30$ $100 \%$ of submicron biomass smoke particles can act as cloud condensation nuclei [Rodgers et al., 1991], the particles emitted by African savanna fires could have important effects on cloud microstructures. 
Table 5. Average Values of Regression Slopes, Regression Intercepts, and Correlation Coefficients $\left(r^{2}\right)$ for Emission Factors $(\mathrm{EF})^{\mathrm{a}}$ Versus Modified Combustion Efficiency (MCE) for Initial Smoke From Savanna Fires Sampled in Southern Africa in This Study

\begin{tabular}{|c|c|c|c|c|}
\hline Species & $\begin{array}{l}\text { Technique Used } \\
\text { for Measurement }\end{array}$ & Slope & Intercept & $r^{2}$ \\
\hline Carbon dioxide $\left(\mathrm{CO}_{2}\right)$ & $\mathrm{GC} / \mathrm{C}$ & 2190 & -357 & 0.96 \\
\hline Carbon monoxide (CO) & $\mathrm{GC} / \mathrm{C}$ & -1150 & 1150 & 0.99 \\
\hline Methane $\left(\mathrm{CH}_{4}\right)$ & $\mathrm{GC} / \mathrm{C}$ & -31 & 31 & 0.69 \\
\hline Nonmethane organic compounds (NMOC) & $\mathrm{GC} / \mathrm{C}$ & -50 & 50 & 0.33 \\
\hline Nitrogen oxides (as NO) & AFTIR & -5.8 & 8.7 & 0.04 \\
\hline Sulfur dioxide $\left(\mathrm{SO}_{2}\right)$ & Teco 43S (via “grab bag”) & -11 & 10 & 0.56 \\
\hline Dimethyl sulfide $\left(\mathrm{CH}_{3} \mathrm{SCH}_{3}\right)$ & $\mathrm{GC} / \mathrm{C}$ & -0.020 & 0.021 & 0.16 \\
\hline Methyl bromide $\left(\mathrm{CH}_{3} \mathrm{Br}\right)$ & $\mathrm{GC} / \mathrm{C}$ & -0.020 & 0.020 & 0.54 \\
\hline Methyl chloride $\left(\mathrm{CH}_{3} \mathrm{Cl}\right)$ & $\mathrm{GC} / \mathrm{C}$ & -0.52 & 0.56 & 0.08 \\
\hline Methyl iodide $\left(\mathrm{CH}_{3} \mathrm{I}\right)$ & $\mathrm{GC} / \mathrm{C}$ & -0.010 & 0.011 & 0.61 \\
\hline Methyl nitrate $\left(\mathrm{CH}_{3} \mathrm{ONO}_{2}\right)$ & $\mathrm{GC} / \mathrm{C}$ & -0.006 & 0.006 & 0.18 \\
\hline Ethane $\left(\mathrm{C}_{2} \mathrm{H}_{6}\right)$ & $\mathrm{GC} / \mathrm{C}$ & -2.9 & 2.9 & 0.44 \\
\hline Ethene $\left(\mathrm{C}_{2} \mathrm{H}_{4}\right)$ & $\mathrm{GC} / \mathrm{C}$ & -10 & 10 & 0.82 \\
\hline Propane $\left(\mathrm{C}_{3} \mathrm{H}_{8}\right)$ & $\mathrm{GC} / \mathrm{C}$ & -0.87 & 0.87 & 0.31 \\
\hline Propene $\left(\mathrm{C}_{3} \mathrm{H}_{6}\right)$ & $\mathrm{GC} / \mathrm{C}$ & -4.5 & 4.4 & 0.72 \\
\hline Acetylene $\left(\mathrm{C}_{2} \mathrm{H}_{2}\right)$ & $\mathrm{GC} / \mathrm{C}$ & -2.8 & 2.8 & 0.62 \\
\hline$i$-butane $\left(i-\mathrm{C}_{4} \mathrm{H}_{10}\right)$ & $\mathrm{GC} / \mathrm{C}$ & -0.090 & 0.087 & 0.39 \\
\hline$n$-butane $\left(n-\mathrm{C}_{4} \mathrm{H}_{10}\right)$ & $\mathrm{GC} / \mathrm{C}$ & -0.28 & 0.28 & 0.62 \\
\hline$t$-2-butene $\left(\mathrm{C}_{4} \mathrm{H}_{8}\right)$ & $\mathrm{GC} / \mathrm{C}$ & -0.28 & 0.28 & 0.77 \\
\hline 1-butene $\left(\mathrm{C}_{4} \mathrm{H}_{8}\right)$ & $\mathrm{GC} / \mathrm{C}$ & -0.80 & 0.79 & 0.61 \\
\hline$c$-2-butene $\left(\mathrm{C}_{4} \mathrm{H}_{8}\right)$ & $\mathrm{GC} / \mathrm{C}$ & -0.20 & 0.20 & 0.70 \\
\hline$i$-pentane $\left(i-\mathrm{C}_{5} \mathrm{H}_{12}\right)$ & $\mathrm{GC} / \mathrm{C}$ & -0.03 & 0.03 & 0.86 \\
\hline$n$-pentane $\left(n-\mathrm{C}_{5} \mathrm{H}_{12}\right)$ & $\mathrm{GC} / \mathrm{C}$ & -0.10 & 0.098 & 0.89 \\
\hline 1, 3-butadiene $\left(\mathrm{C}_{4} \mathrm{H}_{6}\right)$ & $\mathrm{GC} / \mathrm{C}$ & -1.0 & 0.99 & 0.88 \\
\hline 3-methyl-1-butene $\left(\mathrm{C}_{5} \mathrm{H}_{10}\right)$ & $\mathrm{GC} / \mathrm{C}$ & -0.10 & 0.10 & 0.62 \\
\hline$t$-2-pentene $\left(\mathrm{C}_{5} \mathrm{H}_{10}\right)$ & $\mathrm{GC} / \mathrm{C}$ & -0.090 & 0.087 & 0.69 \\
\hline 2-methyl-2-butene $\left(\mathrm{C}_{5} \mathrm{H}_{10}\right)$ & $\mathrm{GC} / \mathrm{C}$ & -0.10 & 0.10 & 0.66 \\
\hline 2-methyl-1-butene $\left(\mathrm{C}_{5} \mathrm{H}_{10}\right)$ & $\mathrm{GC} / \mathrm{C}$ & -0.11 & 0.11 & 0.65 \\
\hline$c$-2-pentene $\left(\mathrm{C}_{5} \mathrm{H}_{10}\right)$ & $\mathrm{GC} / \mathrm{C}$ & -0.050 & 0.047 & 0.58 \\
\hline$n$-hexane $\left(\mathrm{C}_{6} \mathrm{H}_{14}\right)$ & $\mathrm{GC} / \mathrm{C}$ & -0.26 & 0.26 & 0.86 \\
\hline Isoprene $\left(\mathrm{C}_{5} \mathrm{H}_{8}\right)$ & $\mathrm{GC} / \mathrm{C}$ & -0.57 & 0.58 & 0.47 \\
\hline 2-methyl-1-pentene $\left(\mathrm{C}_{6} \mathrm{H}_{12}\right)$ & $\mathrm{GC} / \mathrm{C}$ & -0.07 & 0.68 & 0.65 \\
\hline$n$-heptane $\left(\mathrm{C}_{7} \mathrm{H}_{16}\right)$ & $\mathrm{GC} / \mathrm{C}$ & -0.21 & 0.21 & 0.61 \\
\hline Benzene $\left(\mathrm{C}_{6} \mathrm{H}_{6}\right)$ & $\mathrm{GC} / \mathrm{C}$ & -2.9 & 2.9 & 0.82 \\
\hline Toluene $\left(\mathrm{C}_{7} \mathrm{H}_{8}\right)$ & $\mathrm{GC} / \mathrm{C}$ & -2.1 & 2.1 & 0.31 \\
\hline Formaldehyde (HCHO) & AFTIR & -13.94 & 19.17 & 0.48 \\
\hline Methanol $\left(\mathrm{CH}_{3} \mathrm{OH}\right)$ & AFTIR & -21.28 & 21.17 & 0.80 \\
\hline Acetic acid $\left(\mathrm{CH}_{3} \mathrm{CO}_{2} \mathrm{H}\right)$ & AFTIR & -45.33 & 45.03 & 0.93 \\
\hline Formic acid $\left(\mathrm{HCO}_{2} \mathrm{H}\right)$ & AFTIR & -7.51 & 7.77 & 0.15 \\
\hline Ammonia $\left(\mathrm{NH}_{3}\right)$ & AFTIR & -3.71 & 3.75 & 0.12 \\
\hline Hydrogen cyanide $(\mathrm{HCN})$ & AFTIR & -3.07 & 3.42 & 0.15 \\
\hline Total particulate matter (TPM) & $\mathrm{F} / \mathrm{BH}$ & -292 & 288 & 0.75 \\
\hline Total carbon (TC) & $\mathrm{F} / \mathrm{BH}$ & -43 & 43 & 0.49 \\
\hline Organic carbon (OC) & $\mathrm{F} / \mathrm{GB}$ & -37 & 38 & 0.47 \\
\hline Black carbon (BC) & $\mathrm{F} / \mathrm{GB}$ & -5.8 & 5.8 & 0.47 \\
\hline Chloride $\left(\mathrm{Cl}^{-}\right)$ & $\mathrm{F} / \mathrm{GB}$ & -39 & 38 & 0.38 \\
\hline Nitrate $\left(\mathrm{NO}_{3}^{-}\right)$ & $\mathrm{F} / \mathrm{GB}$ & -2.4 & 2.5 & 0.24 \\
\hline Sulfate $\left(\mathrm{SO}_{4}{ }^{2-}\right)$ & $\mathrm{F} / \mathrm{GB}$ & -5.4 & 5.3 & 0.39 \\
\hline$\underline{\text { Potassium }\left(\mathrm{K}^{+}\right)}$ & $\mathrm{F} / \mathrm{GB}$ & -16 & 16 & 0.45 \\
\hline
\end{tabular}

${ }^{\mathrm{a} E m i s s i o n}$ factors are expressed as grams per kilogram of fuel burned.

${ }^{\mathrm{b}} \mathrm{GC} / \mathrm{C}=$ gas chromatography via canister; F/GB = filters via grab bag; AFTIR = Airborne Fourier Transform Infrared spectroscopy.

[47] Table 4 lists emission factors for eleven species that do not appear in the compilation of emission factors for biomass burning given by Andreae and Merlet [2001]. These species are DMS, methyl nitrate, five hydrocarbons (3-methyl-1-butene, $c$-2-pentene, $t$-2-pentene, 2-methyl-1pentene, and $n$-heptane), the particulate anions $\mathrm{Cl}^{-}, \mathrm{SO}_{4}^{2-}$ and $\mathrm{NO}_{3}^{-}$, and particles in the size range 0.1 to $3 \mu \mathrm{m}$ diameter $\left(\mathrm{CN}_{0.1-3 \mu \mathrm{m}}\right)$. For all these species, the correlation coefficient $\left(r^{2}\right)$ of the excess mixing ratio versus the excess mixing ratio of $\mathrm{CO}$ was $\geq 0.5$, indicating that they were emitted by biomass burning. Except for $\mathrm{Cl}^{-}, \mathrm{SO}_{4}^{2-}$ and $\mathrm{NO}_{3}^{-}$, these species have not been previously reported for biomass burning of savanna in southern Africa. These species are discussed in turn below.

[48] The oxidation of DMS to $\mathrm{SO}_{2}$ can lead subsequently to the formation of sulfate particles. Average emission factors for $\mathrm{DMS}, \mathrm{SO}_{2}$ and $\mathrm{SO}_{4}^{2-}$ from this study are, respectively, $0.0013 \pm 0.001,0.43 \pm 0.30$, and $0.17 \pm$ 0.18 grams per kilogram of fuel burned (Table 4). The large standard deviations in these values reflect the high variability in the emissions of these species, which is not surprising since fuel sulfur content varies greatly. Nevertheless, the average value of the emission factor for DMS is about a factor of 100 below that of $\mathrm{SO}_{2}$ and $\mathrm{SO}_{4}^{2-}$. There- 

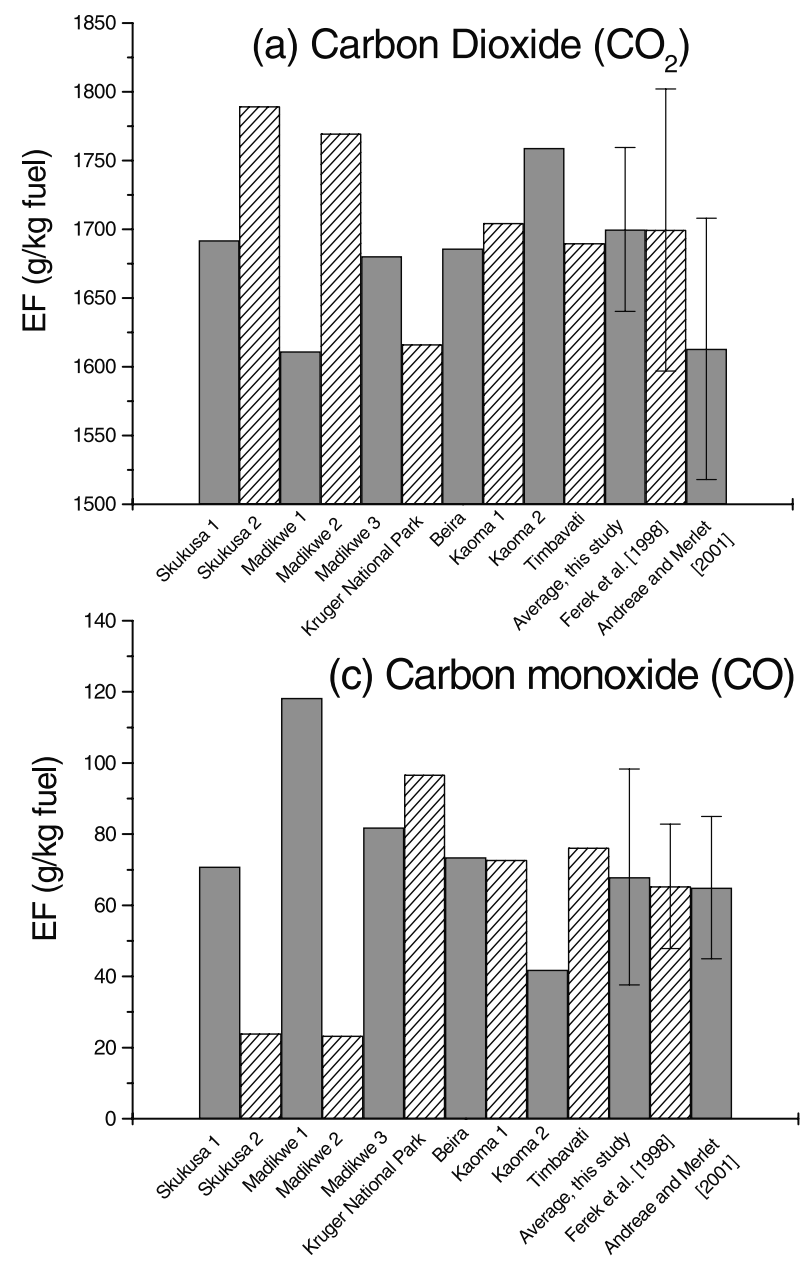
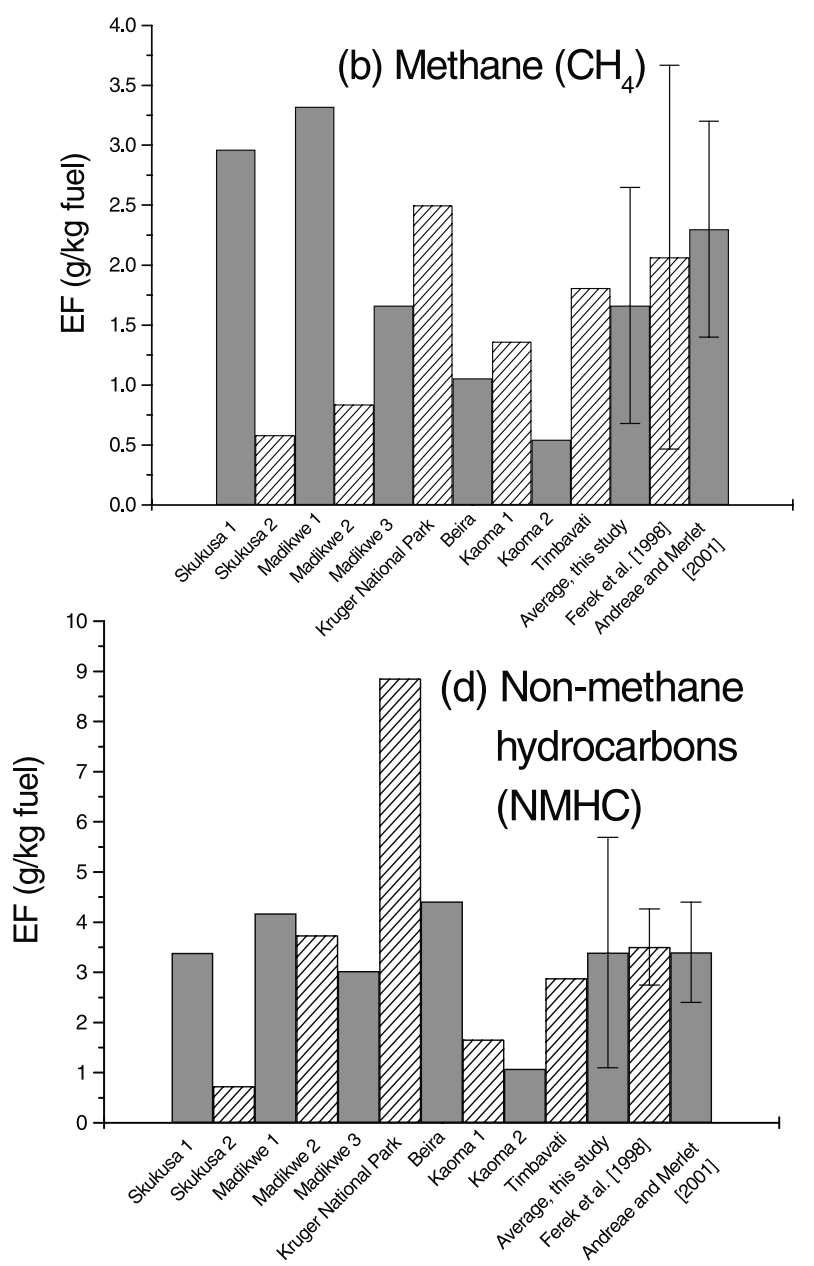

Figure 5. Emission factors (EF) for $\mathrm{CO}_{2}, \mathrm{CO}, \mathrm{CH}_{4}$, and $\mathrm{NMHC}$, derived from canister measurements, for the burning of savanna in southern Africa (this study), grassland in Brazil [Ferek et al., 1998], and global savanna burning [Andreae and Merlet, 2001].

fore, on average, the direct emission of $\mathrm{SO}_{4}^{2-}$ from the fires probably dominated over the subsequent production of $\mathrm{SO}_{4}^{2-}$ through DMS oxidation, but not over $\mathrm{SO}_{4}^{2-}$ production due to the oxidation of $\mathrm{SO}_{2}$ emitted directly from the fires.

[49] Methyl nitrate $\left(\mathrm{CH}_{3} \mathrm{ONO}_{2}\right)$ can serve to redistribute $\mathrm{NO}_{2}$ in regions distant from its source, which can then lead to $\mathrm{O}_{3}$ formation [Warneck, 2000]. The average emission factor for $\mathrm{CH}_{3} \mathrm{ONO}_{2}$ measured in this study of young smoke is only $0.00051 \pm 0.00037$ grams per kilogram of fuel burned, compared to $3.3 \pm 0.6 \mathrm{~g} \mathrm{~kg}^{-1}$ for $\mathrm{NO}_{\mathrm{x}}$ as $\mathrm{NO}$ (Table 4). However, $\mathrm{CH}_{3} \mathrm{ONO}_{2}$ and $\mathrm{NO}_{\mathrm{x}}$ could have comparable mixing ratios in older smoke.

[50] The five new hydrocarbons we detected in the smoke over the fires are reactive alkanes and alkenes. Because the $\mathrm{OH}$ radical is a major oxidant for these five hydrocarbons, their presence will reduce the concentration of $\mathrm{OH}$, and therefore oxidation by $\mathrm{OH}$, downwind in smoke plumes. All five hydrocarbons decreased significantly as the smoke aged [Hobbs et al., 2003].

[51] The emission factors for $\mathrm{Cl}^{-}, \mathrm{SO}_{4}^{2-}$ and $\mathrm{NO}_{3}^{-}$ reported here, namely, $0.97 \pm 1.4,0.16 \pm 0.11$ and $0.17 \pm$ $0.18 \mathrm{~g} \mathrm{~kg}^{-1}$, respectively, can be compared with the corresponding values given for savanna, forest and agricul- tural fires in southern Africa by Andreae et al. [1998], namely, $1.40 \pm 0.35,0.37 \pm 0.20$ and $0.59 \pm 0.24$, respectively. The values given by Andreae et al. may be larger because of higher nutrient content in agricultural fuels and/ or because they sampled older smoke than we did.

[52] Emission factors for the particulate ionic species can be compared to their most abundant corresponding gaseous species. For example, the molar ratio of the emission factors of $\mathrm{NO}_{3}^{-}$to $\mathrm{NO}_{\mathrm{x}}$ is 0.022 , and the molar ratio of the emission factors of $\mathrm{SO}_{4}^{2-}$ to $\mathrm{SO}_{2}$ is 0.26 . These ratios indicate that most of the nitrogen released from the fires was in gaseous form as $\mathrm{NO}_{\mathrm{x}}$, and about four times as much $\mathrm{SO}_{2}$ was released as was $\mathrm{SO}_{4}^{2-}$. Furthermore, chemical transformations from $\mathrm{NO}_{\mathrm{x}}$ to nitrate, and from $\mathrm{SO}_{2}$ to sulfate, could have occurred even in the initial smoke. However, the latter transformation must have occurred more rapidly than the former. The molar ratio of the emission factor of $\mathrm{Cl}^{-}$to $\mathrm{CH}_{3} \mathrm{Cl}$ is 20 , which suggests that most of the chlorine released was in particulate form as $\mathrm{Cl}^{-}$.

[53] The emission factors for $\mathrm{Cl}^{-}, \mathrm{NO}_{3}^{-}$and $\mathrm{SO}_{3}^{2-}$ can be compared with those for $\mathrm{K}^{+}$and $\mathrm{NH}_{3}$, to check the balance between emissions of positive and negative ions. The emission factors for $\mathrm{K}^{+}$and $\mathrm{Cl}^{-}$are $0.50 \pm 0.53$ and 0.97 $\pm 1.4 \mathrm{~g} \mathrm{~kg}^{-1}$ (or $0.013 \pm 0.014$ and $0.027 \pm 0.039 \mathrm{~mol}$ 

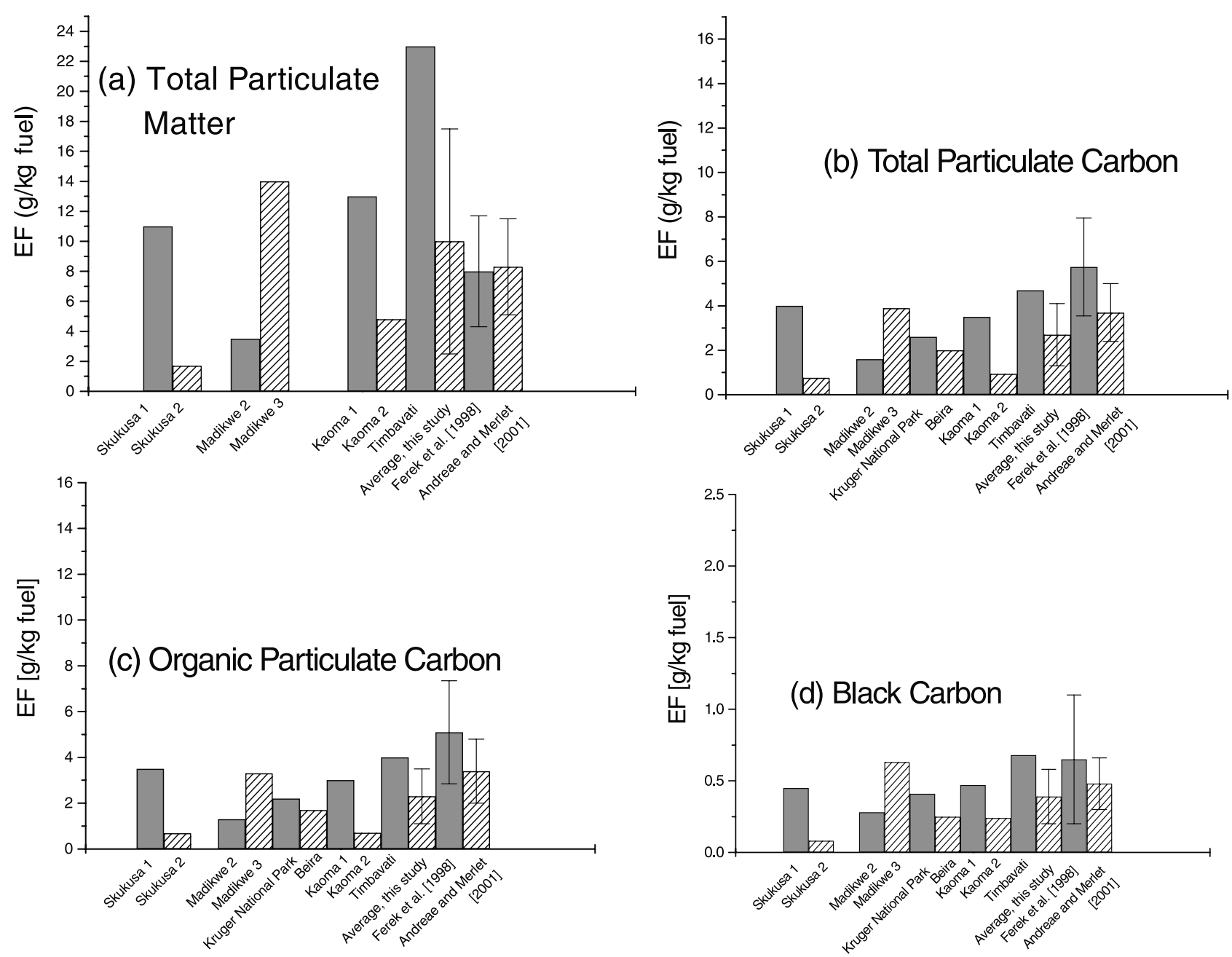

Figure 6. As for Figure 5 but for total particulate matter, total particulate carbon, organic particulate carbon and black carbon.

$\left.\mathrm{kg}^{-1}\right)$, respectively, which are not significantly different $\left(\mathrm{K}^{+}\right.$ and $\mathrm{Cl}^{-}$can form the neutral $\mathrm{KCl}$ ). Ammonia is the primary basic gas in the atmosphere, which can neutralize $\mathrm{HNO}_{3}$ and $\mathrm{H}_{2} \mathrm{SO}_{4}$. The emission factor for $\mathrm{NH}_{3}$ is $0.26 \pm 0.15 \mathrm{~g}$ $\mathrm{kg}^{-1}$ (or $0.015 \pm 0.009 \mathrm{~mol} \mathrm{~kg}{ }^{-1}$ ), while the sum of the emission factors for $\mathrm{NO}_{3}^{-}$and $\mathrm{SO}_{4}^{2-}$ is $0.33 \pm 0.21 \mathrm{~g} \mathrm{~kg}^{-1}$ (or $0.0044 \pm 0.0026 \mathrm{~mol} \mathrm{~kg}{ }^{-1}$ ). These comparisons indicate that, on average and within the variability of the measurements, the positive and negative ions emitted by the fires were in charge balance.

[54] Aerosol surface area is one of the main factors that determines the rates of heterogeneous reactions, and most of the surface area of aerosols in the atmosphere is associated with accumulation mode particles, which have peak concentrations at a diameter of about $0.1 \mu \mathrm{m}$. Also, since accumulation mode particles are not removed very efficiently from the atmosphere, they have relatively long residence times [e.g., Hobbs, 2000]. As shown in Table 4, the average emission factor of particles with diameters from 0.1 to $3 \mu \mathrm{m}$ (i.e., accumulation-mode particles) from savanna burning in southern Africa measured in this study was $(2.0 \pm 1.5) \times 10^{14}$ particles per kilogram of fuel burned, compared to $(3.0 \pm 1.7) \times 10^{16}$ total $(\mathrm{CN})$ particles emitted per kilogram of fuel burned. If it is assumed that all particles in the accumulation mode have a diameter of $0.1 \mu \mathrm{m}$, the emission factor for the surface area of these particles is $(6.3$ $\pm 4.7) \mathrm{m}^{2}$ per kilogram of fuel.

[55] Based on the $\mathrm{CN}_{0.1-3} \mu \mathrm{m}$ and $\mathrm{CN}$ emission factors, only $\sim 1 \%$ by number of the particles in the initial smoke were in the accumulation mode. Particle size spectra measured with the DMPS showed that the particle mode diameter in the initial smoke was $\sim 0.01 \mu \mathrm{m}$, with most of the particles ranging from $\sim 0.01-0.03 \mu \mathrm{m}$. As smoke ages, particle coagulation and gas-to-particle conversion increase the particle mode diameter [Hobbs et al., 2003].

\section{Comparisons of Measurements Using Gas Chromatography and Fourier Transform Infrared Spectroscopy}

[56] In laboratory studies, Goode et al. [1999] obtained excellent agreement for the concentrations of a number of gaseous species measured in the same biomass smoke by gas chromatography on canister samples $(\mathrm{GC} / \mathrm{C})$ and by Fourier transform infrared spectroscopy. In the field studies described in the present paper, five species $\left(\mathrm{CO}_{2}, \mathrm{CO}, \mathrm{CH}_{4}\right.$, $\mathrm{C}_{2} \mathrm{H}_{2}$ and $\mathrm{C}_{2} \mathrm{H}_{4}$ ) were measured by both $\mathrm{GC} / \mathrm{C}$ and by AFTIR. This provides a unique opportunity to compare 

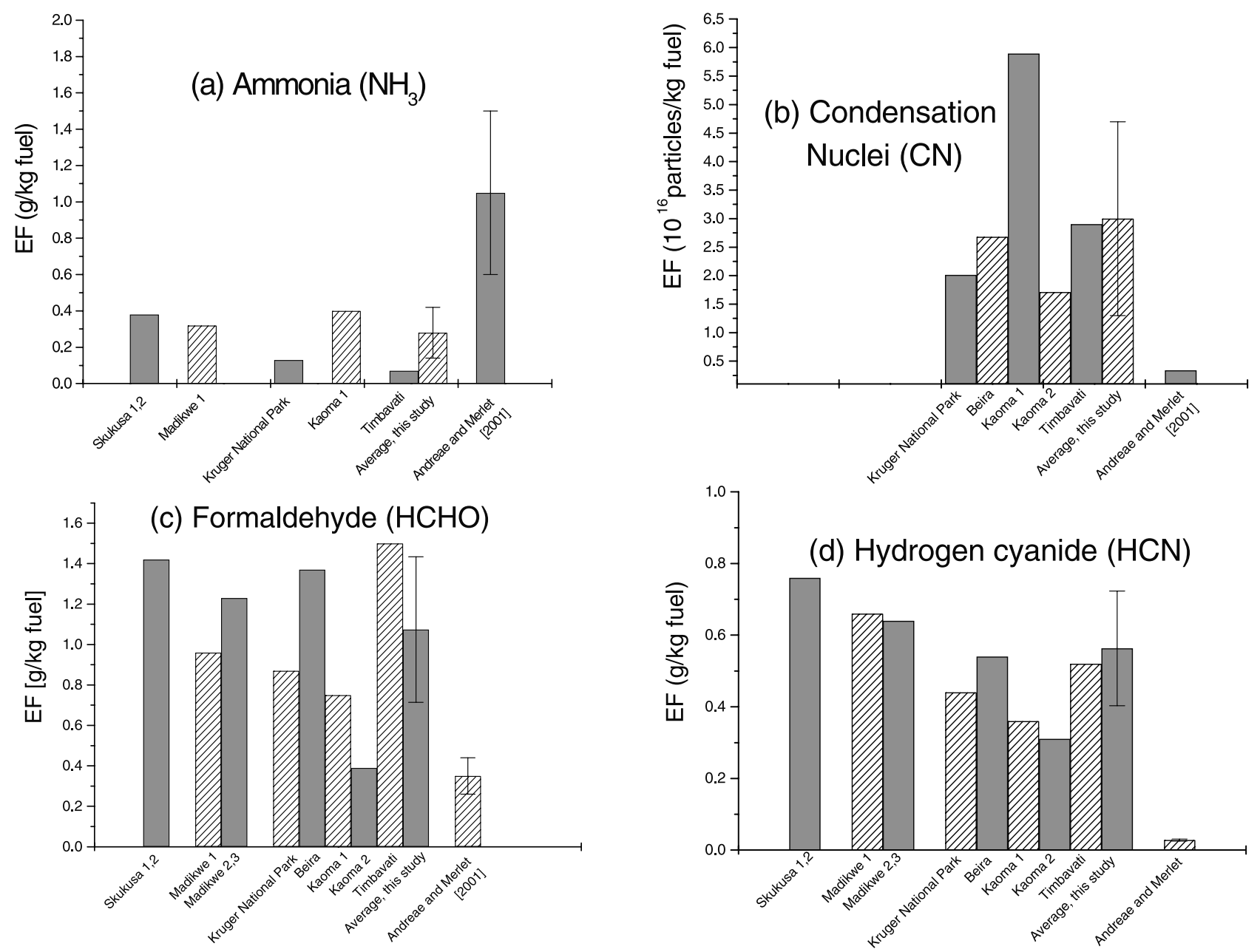

Figure 7. Emission factors (EF) for ammonia, condensation nuclei, formaldehyde, and hydrogen cyanide from the burning of savanna in southern Africa measured in this study compared to those given for global savanna burning by Andreae and Merlet [2001].

measurements from these two independent techniques under field conditions. However, in doing so it should be pointed out that in the present study the GC/C and AFTIR measurements were not made on exactly the same smoke samples. Also, whereas a single ambient $\mathrm{GC} / \mathrm{C}$ sample was obtained for each fire, multiple ambient AFTIR measurements were obtained.

[57] Shown in Table 6 are comparisons of both emission factors and MCEs derived from the $\mathrm{GC} / \mathrm{C}$ and AFTIR measurements for the 10 fires described in this paper. The emission factors derived from these two independent measuring techniques are in good agreement for the Madikwe 2, 3, Kruger National Park, Kaoma 1, and Kaoma 2, and the Timbavati fires. For these fires, the MCE derived from the GC/C and AFTIR measurements are either identical or similar, indicating that similar smoke was sampled by both techniques. For the Skukuza 1, 2 and Beria fires, the smoke sampled for the $\mathrm{GC} / \mathrm{C}$ measurements had higher average MCEs than the smoke sampled by the AFTIR. Consistent with this, the emission factor for $\mathrm{CO}_{2}$ was greater, and the emission factors for the smoldering products $\left(\mathrm{CO}, \mathrm{CH}_{4}\right.$, $\mathrm{C}_{2} \mathrm{H}_{2}$ and $\mathrm{C}_{2} \mathrm{H}_{4}$ ) were lower from the $\mathrm{GC} / \mathrm{C}$ measurements than from the AFTIR. The reverse was true for the Madikwe
1 fire, where the smoke sampled for the $\mathrm{GC} / \mathrm{C}$ measurements had a lower MCE than the smoke sampled by the AFTIR. We conclude from these results that the $\mathrm{GC} / \mathrm{C}$ and AFTIR provided similar results when they sampled similar smoke.

[58] Comparisons of study-average emission ratios and emission factors for $\mathrm{CO}_{2}, \mathrm{CO}, \mathrm{CH}_{4}, \mathrm{C}_{2} \mathrm{H}_{2}$ and $\mathrm{C}_{2} \mathrm{H}_{4}$ derived from the $\mathrm{GC} / \mathrm{C}$ and AFTIR are shown in Figure 8. The values obtained from the two techniques are in good agreement, with the exception of $\mathrm{C}_{2} \mathrm{H}_{4}$ (ethene). The average emission ratios for $\mathrm{C}_{2} \mathrm{H}_{4}$ from $\mathrm{GC} / \mathrm{C}$ and AFTIR are 0.0110 \pm 0.0005 and $0.017 \pm 0.003$, respectively. Ferek et al. [1998] reported a $\mathrm{C}_{2} \mathrm{H}_{4}$ emission ratio of 0.011 obtained by $\mathrm{GC} / \mathrm{C}$ for young smoke from grass, cerrado, and forest fires in Brazil. Blake et al. [1996] reported $\mathrm{C}_{2} \mathrm{H}_{4}$ emission ratios from $\mathrm{GC} / \mathrm{C}$ of $0.0083 \pm 0.0006$ and $0.0061 \pm 0.0004$ for young and aged smoke (with depleted $\mathrm{C}_{2} \mathrm{H}_{4}$ ) from savanna fires in southern Africa and from agricultural fires in Brazil, respectively. Hence, the $\mathrm{C}_{2} \mathrm{H}_{4}$ emission ratios measured by several workers using $\mathrm{GC} / \mathrm{C}$ are lower in magnitude than those obtained in this study using AFTIR, although this was not the case in the work of Goode et al. [1999]. 
Table 6. Modified Combustion Efficiency (MCE) and Emission Factors ${ }^{\mathrm{a}}$ Measured by Gas Chromatography on Canister Samples (GC/ C) and by Airborne Fourier Transform Infrared Spectroscopy (AFTIR) ${ }^{\mathrm{b}}$

\begin{tabular}{|c|c|c|c|c|c|c|c|c|c|c|}
\hline Measurement & $\begin{array}{l}\text { Technique Used } \\
\text { for Measurement }\end{array}$ & $\begin{array}{c}\text { Skukuza } \\
1,2^{\mathrm{c}}\end{array}$ & Madikwe 1 & $\begin{array}{c}\text { Madikwe } \\
2,3^{\mathrm{c}}\end{array}$ & $\begin{array}{c}\text { Kruger } \\
\text { National Park }\end{array}$ & Beira & Kaoma 1 & Kaoma 2 & Timbavati & $\begin{array}{c}\text { Study } \\
\text { Average }\end{array}$ \\
\hline \multirow[t]{2}{*}{ MCE } & $\mathrm{GC} / \mathrm{C}$ & 0.96 & 0.90 & 0.96 & 0.93 & 0.95 & 0.94 & 0.96 & 0.94 & $0.94 \pm 0.02$ \\
\hline & AFTIR & 0.93 & 0.94 & 0.96 & 0.93 & 0.91 & 0.94 & 0.97 & 0.94 & $0.94 \pm 0.02$ \\
\hline \multicolumn{11}{|l|}{ Emission factor } \\
\hline \multirow[t]{2}{*}{ Carbon dioxide } & $\mathrm{GC} / \mathrm{C}$ & 1741 & 1611 & 1726 & 1616 & 1686 & 1705 & 1759 & 1690 & $1700 \pm 51$ \\
\hline & AFTIR & 1678 & 1715 & 1738 & 1688 & 1643 & 1711 & 1779 & 1696 & $1706 \pm 38$ \\
\hline \multirow[t]{2}{*}{ Carbon monoxide } & $\mathrm{GC} / \mathrm{C}$ & 48 & 120 & 53 & 97 & 73 & 73 & 42 & 76 & $68 \pm 24$ \\
\hline & AFTIR & 84 & 64 & 51 & 78 & 103 & 69 & 30 & 75 & $69 \pm 21$ \\
\hline \multirow{2}{*}{ Methane } & $\mathrm{GC} / \mathrm{C}$ & 1.8 & 3.3 & 1.3 & 2.5 & 1.1 & 1.4 & 0.5 & 1.8 & $1.7 \pm 0.8$ \\
\hline & AFTIR & 2.8 & 2.0 & 1.4 & 3.1 & 3.6 & 1.4 & 0.6 & 2.5 & $2.2 \pm 0.9$ \\
\hline \multirow[t]{2}{*}{ Ethene } & $\mathrm{GC} / \mathrm{C}$ & 0.55 & 1.1 & 0.56 & 0.77 & 0.78 & 0.43 & 0.38 & 0.73 & $0.64 \pm 0.22$ \\
\hline & AFTIR & 1.61 & 0.97 & 1.02 & 1.22 & 1.60 & 0.82 & 0.69 & 1.19 & $1.14 \pm 0.31$ \\
\hline \multirow[t]{2}{*}{ Acetylene } & $\mathrm{GC} / \mathrm{C}$ & 0.17 & 0.27 & 0.20 & 0.29 & 0.35 & 0.16 & 0.16 & 0.23 & $0.22 \pm 0.07$ \\
\hline & AFTIR & 0.26 & 0.22 & 0.26 & 0.31 & 0.36 & 0.24 & 0.20 & 0.24 & $0.26 \pm 0.05$ \\
\hline
\end{tabular}

${ }^{\mathrm{a}}$ Emission factors expressed as grams of species emitted per kilogram of fuel burned.

${ }^{\mathrm{b}} \mathrm{A}$ total of $16 \mathrm{GC} / \mathrm{C}$ samples and 36 AFTIR samples were obtained for the 10 fires listed.

${ }^{\mathrm{c}}$ Measurements for Skukuza 1 and 2 are averaged together since they were obtained on similar fires located close together on the same day; similarly for Madikwe 2 and 3.

[59] The study-average emission factors for $\mathrm{C}_{2} \mathrm{H}_{4}$ from the $\mathrm{GC} / \mathrm{C}$ and AFTIR are $0.64 \pm 0.22$ and $1.14 \pm 0.31$ grams per kilogram of fuel burned, respectively. If these two average values are weighted by the number of samples obtained for the $\mathrm{GC} / \mathrm{C}$ and AFTIR measurements (16 and 36 , respectively), and then combined to yield an overall study-average for the emission factor of $\mathrm{C}_{2} \mathrm{H}_{4}$, the value obtained is $0.99 \pm 0.28$ grams per kilogram of fuel burned. Andreae and Merlet [2001] give a value of $(0.79 \pm 0.56)$ $\mathrm{g} / \mathrm{kg}$ for the emission factor of $\mathrm{C}_{2} \mathrm{H}_{4}$ from savanna and grassland fires.

\section{Emission Fluxes}

[60] Table 7 provides estimates of emission fluxes for those species that have not been reported previously as emissions from African savanna fires and those for which the emission factors given in this paper differ significantly from previously published values. The emission fluxes were estimated by multiplying the study-average emission factors given in Table 4 by estimates of the total amount of savanna burned in Africa and worldwide. For African savanna fires we used the estimate of $1600 \mathrm{Tg} \mathrm{yr}^{-1}$ reported by Hao and Liu [1994], and for savanna fires worldwide we used an estimate of $1410 \mathrm{Tg}$ (C) $\mathrm{yr}^{-1}$ [Lobert et al., 1999], or assuming a carbon content for savanna fuels of $50 \%$, $2820 \mathrm{Tg}$ fuel $\mathrm{yr}^{-1}$.

[61] In the case of DMS, ammonia and formaldehyde, emissions from savanna fires are minor in comparison to total global sources. However, emissions from African and global savanna fires contribute $\sim 40 \%$ and $\sim 70 \%$, respectively, of the global emissions of HCN. Total global sources of the other species listed in Table 7 are unknown.

[62] The emission fluxes for savanna fires given in Table 7 are based on the study-average emission factors given in this paper. However, Table 4 provides emission factors for 10 fires covering various savanna types, including the lowveld and bushveld dry savanna biomes and the miombo and dambo humid savanna biomes. Hao and Liu [1994] provide the spatial distribution of African savanna burning with a resolution of $5^{\circ}$ latitude by $5^{\circ}$ longitude for the fourth month of the burning season during the late 1970s. For the $5^{\circ}$ by $5^{\circ}$ cell covering southern Congo, which is a region of predominantly miombo woodland, Hao and Liu estimated that $9 \mathrm{Tg}$ of savanna were burned in that month. To estimate emissions of a species from southern Congo during that month, the appropriate emission factor from the Kaoma 1 fire (Table 4) could be used since this fire occurred in miombo woodland. Using vegetation-specific emission factors for all the months of the burning season in Africa would yield more accurate annual flux estimates than those given in Table 7. However, such estimates require a spatially and temporally resolved database for the quantity and type of savanna burned throughout Africa over the entire burning season.

\section{Summary and Conclusions}

[63] In this paper we have reported emission ratios and emission factors for 50 species in initial smoke from savanna fires in southern Africa. Apart from $\mathrm{CN}$ and $\mathrm{CN}_{0.1-3 \mu \mathrm{m}}$, the emission factors for all these species are summarized in Figure 9. The correlation coefficients $\left(r^{2}\right)$ of the excess mixing ratio of these species versus the excess mixing ratio of $\mathrm{CO}$ or $\mathrm{CO}_{2}$ were all $\geq 0.5$; accordingly, these species were considered to be emitted by the fires. The fuels burned in the fires sampled represent vegetation types from the lowveld to the highveld in South Africa, to dambo and miombo woodlands in Zambia, to east African coastal mosaic in Mozambique (Table 1).

[64] For most species, there is good agreement between the emission ratios and emission factors reported here for initial smoke from savanna fires in southern Africa and those given by Ferek et al. [1998] for initial smoke from fires in Brazil and (for stable compounds) by Blake et al. [1996] for mainly aged smoke from savanna fires in southern Africa, as well as with a recent compilation of measured and estimated emission factors for savanna burning worldwide by Andreae and Merlet [2001]. However, this study provides the first measurements of numerous species in initial smoke from savanna fires in southern Africa, and the first measurements for eight species that have not been reported previously. In some cases, the emission ratios and emission factors given here differ significantly from the 

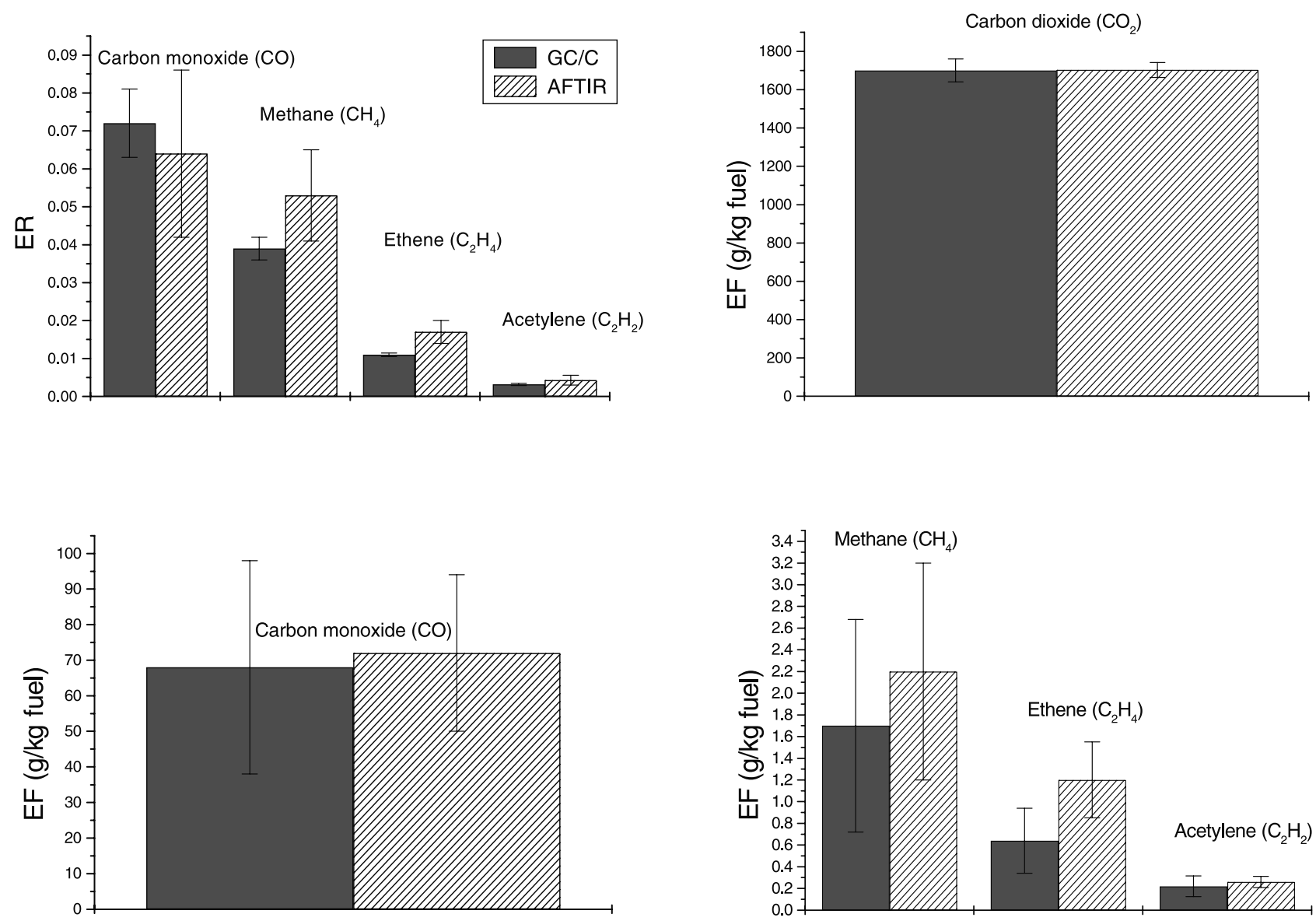

Figure 8. Comparisons of molar emission ratios (ER) and emission factors (EF) for savanna fires in southern Africa for carbon monoxide (with respect to $\mathrm{CO}_{2}$ ) and methane, ethane and acetylene (with respect to $\mathrm{CO}$ ), and emission factors for carbon dioxide, carbon monoxide, methane, ethane and acetylene, calculated from two independent measurement techniques: gas chromatography on canister samples and AFTIR.

measured or estimated emission factors reported in previous studies.

[65] The completely new emission ratios and emission factors given in this paper for young smoke from savanna fires in southern Africa are for dimethyl sulfide, methyl nitrate, five hydrocarbons (3-methyl-1-butene, $c$-2-pentene, $t$-2-pentene, 2-methyl-1-pentene, and $n$-heptane), and particles with diameters from 0.1 to $3 \mu \mathrm{m}$. For all of these

Table 7. Emission Fluxes ${ }^{\mathrm{a}}$ for Species Whose Emission Factors Have Not Been Reported Previously for African Savanna Fires and Those for Which the Emission Factors Given in This Paper Differ Significantly From Previous Estimates

\begin{tabular}{lccc}
\hline \multicolumn{1}{c}{ Species } & Savanna in Africa & Savanna Worldwide & All Global Sources \\
\hline Dimethyl sulfide $\left(\mathrm{C}_{2} \mathrm{H}_{6} \mathrm{~S}\right)$ & $2.1 \pm 1.8$ & $3.7 \pm 3.1$ & $30,000-50,000^{\mathrm{b}}$ \\
Methyl nitrate $\left(\mathrm{CH}_{3} \mathrm{ONO}_{2}\right)$ & $0.82 \pm 0.59$ & $14.4 \pm 9.6$ \\
3-methyl-1-butene $\left(\mathrm{C}_{5} \mathrm{H}_{10}\right)$ & $8.2 \pm 5.4$ & $12.7 \pm 7.9$ \\
t-2-pentene $\left(\mathrm{C}_{5} \mathrm{H}_{10}\right)$ & $7.2 \pm 4.5$ & $7.1 \pm 5.1$ \\
c-2-pentene $\left(\mathrm{C}_{5} \mathrm{H}_{10}\right)$ & $4.0 \pm 2.9$ & $9.9 \pm 5.9$ \\
2-methyl-1-pentene $\left(\mathrm{C}_{6} \mathrm{H}_{12}\right)$ & $5.6 \pm 3.4$ & $20 \pm 20$ \\
n-heptane $\left(\mathrm{C}_{7} \mathrm{H}_{16}\right)$ & $11 \pm 11$ & $3,100 \pm 1,070$ \\
Formaldehyde $(\mathrm{HCHO})$ & $1,760 \pm 610$ & $730 \pm 390$ \\
Ammonia $\left(\mathrm{NH}_{3}\right)$ & $420 \pm 220$ & $1,490 \pm 420$ & $(8.5 \pm 4.8) \times 10^{28}$ \\
Hydrogen $\mathrm{Cyanide}(\mathrm{HCN})$ & $850 \pm 240$ & $(5.6 \pm 4.2) \times 10^{26}$ \\
Condensation nuclei $(\mathrm{CN})$ & $(4.8 \pm 2.7) \times 10^{28}$ &
\end{tabular}

${ }^{\mathrm{a}}$ Emission fluxes are measured in ${\mathrm{Gg} \mathrm{yr}^{-1}}^{-1}$

beinfeld and Pandis [1998].

${ }^{\mathrm{c}}$ From $\mathrm{OH}$ oxidation of methane. Industrial combustion emits an unknown quantity [Hobbs, 2000].

${ }^{\mathrm{d}}$ Li et al. [2000]. 


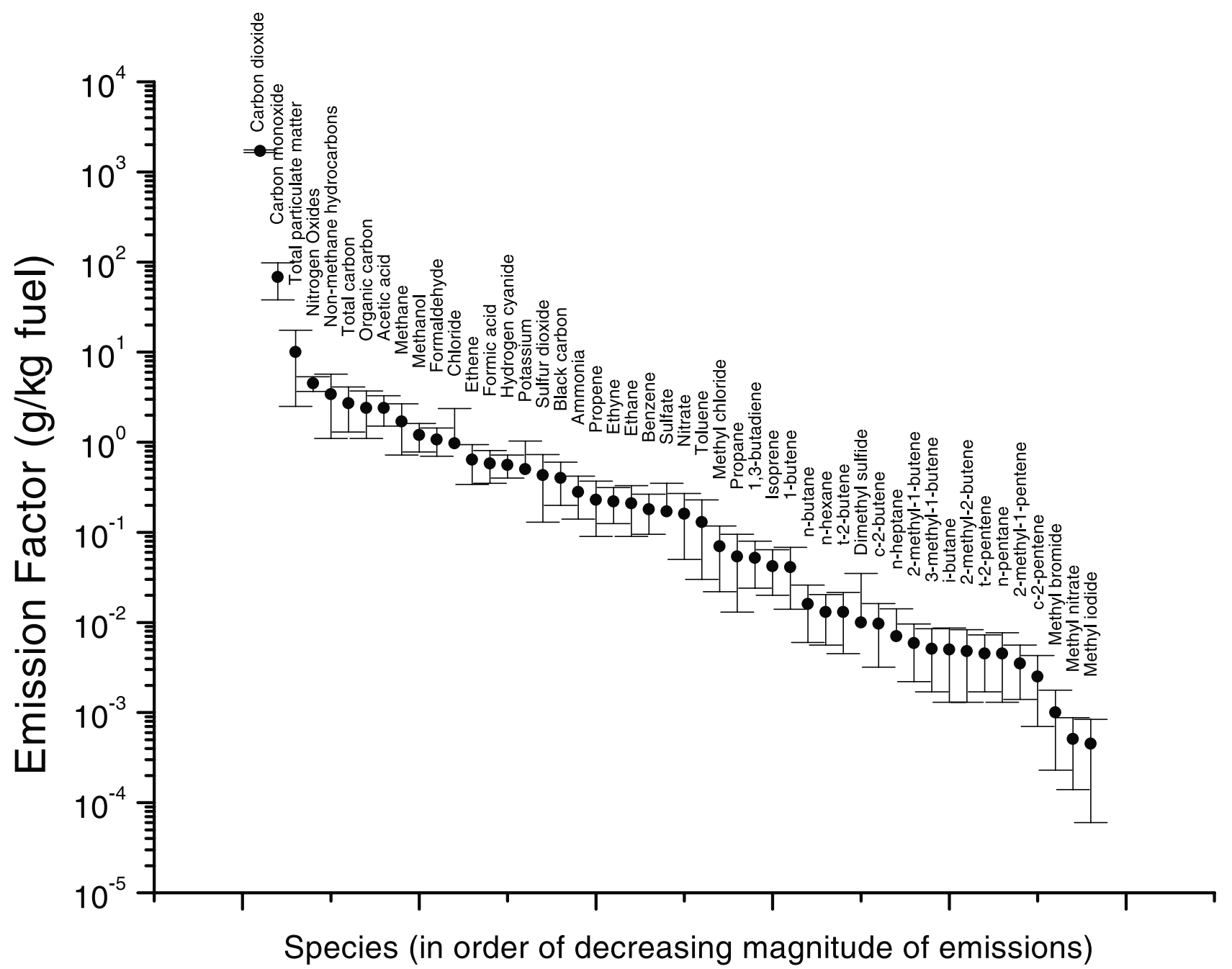

Figure 9. Mean and standard deviations of emission factors for forty-eight gaseous and particulate species based on measurements from 10 savanna fires in southern Africa in this study (see Table 1 for information on the fires). Emission factors for $\mathrm{CN}$ and $\mathrm{CN}_{0.1-3 \mu \mathrm{m}}$ are not shown.

species the correlation coefficients $\left(r^{2}\right)$ of the excess mixing ratio versus the excess mixing ratio of $\mathrm{CO}$ was $\geq 0.5$, indicating that they were emitted by the fires. Of particular interest are methyl nitrate, which can redistribute active nitrogen species and lead to ozone formation; the hydrocarbons, which will reduce the concentrations of $\mathrm{OH}$ in smoke plumes; and, particles in the accumulation mode, which have long residence times in the atmosphere, can act as cloud condensation nuclei, and promote heterogeneous reactions.

[66] The emission factors reported here that differ significantly from those given for savanna fires by Andreae and Merlet [2001] are ammonia, formaldehyde, hydrogen cyanide, and condensation nuclei. Our emission factor for ammonia is about one-fourth that given by Andreae and Merlet, and our emission factors for formaldehyde, hydrogen cyanide, and condensation nuclei are greater by factors of about 3,20 and 3-15, respectively, than those of Andreae and Merlet. Emissions of formaldehyde, and other oxygenated organic compounds, should increase regional ozone production [Mason et al., 2001]. Abundant hydrogen cyanide emissions support the proposed use of this species, which can be monitored from satellites, for detecting smoke from biomass burning [ $\mathrm{Li}$ et al., 2000]. Multiplying the average emission factor given here for condensation nuclei, namely, $(3.0 \pm 1.7) \times 10^{16}$ particles per kilogram of fuel burned by the estimate of Hao and Liu [1994] of $1600 \mathrm{Tg}$ $\mathrm{yr}^{-1}$ for savanna burned in Africa, yields $\sim 2 \times 10^{28}$ to $8 \times$ $10^{28}$ particles per year emitted from African savanna fires. This estimate is about a factor of 10 greater than that given by Le Canut et al. [1996] for particles emitted worldwide by savanna fires.

[67] The emission factors reported here for total particulate matter, total particulate carbon, organic particulate carbon, and black carbon show large variations from one fire to another. However, our average values for these species do not differ significantly from those given by Andreae and Merlet [2001] for savanna fires (see Table 4 and Figure 6).

[68] Emission ratios and emission factors for five species $\left(\mathrm{CO}_{2}, \mathrm{CO}, \mathrm{CH}_{4}, \mathrm{C}_{2} \mathrm{H}_{2}\right.$, and $\left.\mathrm{C}_{2} \mathrm{H}_{4}\right)$ were obtained by gas chromatography and Fourier transform infrared spectroscopy. This provided a unique opportunity to compare measurements from two independent techniques under field conditions. Except for $\mathrm{C}_{2} \mathrm{H}_{4}$, study-average emission ratios 
and emission factors obtained by these two methods were not significantly different.

[69] Finally, it should be emphasized that the emission ratios and emission factors given in this paper are for initial smoke, that is, for smoke less than a few minutes old. Many species are transformed as smoke ages. These transformations are discussed in a companion paper [Hobbs et al., 2003].

\section{Appendix A: An Overview of the University of Washington's Airborne Measurements in the SAFARI 2000 Field Study in Southern Africa, by P. V. Hobbs}

\section{A1. Introduction}

[70] The main goals of the University of Washington (UW) and its guest investigators in the Southern African Regional Science Initiative (SAFARI 2000) were to use its Convair-580 research aircraft facility (Figure A1) to:

1. Measure the physical and chemical properties of aerosols and trace gases in ambient air in the mixed layer and in the free troposphere at various locations in southern Africa.

2. Measure the nature and concentrations of aerosols and trace gases, and their emission factors, in smoke from prescribed and nonprescribed fires of biomass.

3. Obtain measurements on aerosols, trace gases, clouds, and surface properties for comparisons with simultaneous remote sensing measurements from the NASA Terra satellite and ER-2 aircraft, and from SAFARI 2000 ground stations in southern Africa.

4. Measure the spectral albedo and bidirectional reflection distribution function (BRDF) of various surfaces and of clouds in southern Africa.

5. Measure the microstructures of clouds off the South Atlantic Ocean coast of southern Africa.

6. Investigate aerosol-cloud interactions off the South Atlantic Ocean coast of southern Africa.

[71] The field study was carried out from 10 August to 18 September 2000. This is the dry season in southern Africa when biomass burning is widespread. From 10 August to 9 September the Convair-580 was based in Pietersburg, South Africa. During this period twenty-five research flights were carried out over South Africa, Botswana, Zambia and Mozambique. From 10 to 18 September 2000, the Convair-580 was based in Walvis Bay, Namibia, where five flights were made over Namibia and off the west coast of southern Africa.

[72] This appendix provides information on the instrumentation aboard the Convair-580, the aircraft sampling strategies, the flights of the Convair-580 in SAFARI 2000 and their main accomplishments, an overview of some of the ongoing studies of the data collected aboard the Convair580 , and some of the studies of the data yet to be carried out.

\section{A2. Measurements Made Aboard the Convair-580 Aircraft}

[73] The instrumentation aboard the UW Convair-580 research aircraft for the SAFARI 2000 field study is listed in Table A1. In addition to the large number of instruments for which the UW was responsible, several instruments were provided by guest investigators (see Table A1).

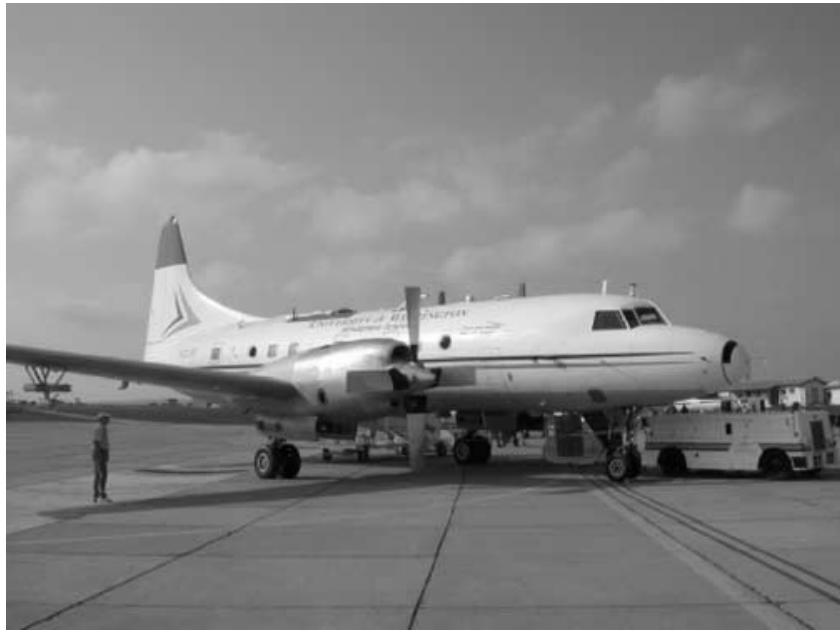

Figure A1. University of Washington's Convair-580 research aircraft in Pietersburg, South Africa, for SAFARI 2000 .

[74] The instrumentation provided measurements of navigational and aircraft flight characteristics; meteorological state parameters (temperature, humidity, winds); comprehensive measurements of aerosol concentrations and size spectra (from 0.01 to $47 \mu \mathrm{m}$ diameter); light scattering, absorption and extinction; aerosol humidographs; aerosol shape and elemental composition; cloud condensation nuclei (for flights based out of Walvis Bay only); aerosol composition and mass; aerosol optical depths; cloud and precipitation size distributions; cloud liquid water content and cloud droplet effective radius; concentrations of $\mathrm{SO}_{2}$, $\mathrm{O}_{3}, \mathrm{CO}_{2}, \mathrm{CO}, \mathrm{NO}, \mathrm{NO}_{\mathrm{x}}$, hydrocarbons, reactive and stable gaseous combustion emissions; column water vapor and ozone; upwelling and downwelling broadband visible, nearinfrared, and ultraviolet radiation; solar spectral irradiances and radiances; and, albedos and the bidirectional reflection distribution function (BRDF) of surfaces and clouds.

[75] Some of the instrumentation and techniques used for the aerosol and gas measurements required sampling times longer than it typically took the aircraft to penetrate an individual smoke plume. In this case, a "grab-bag" technique was employed, in which a $2.5 \mathrm{~m}^{3}$ electrically conducting plastic (Velostat) bag was rapidly filled by ram air. With a $12 \mathrm{~s}$ fill time, the bag sampler was able to capture a relatively large volume of smoke over a small distance in the plume. The smoke samples were then drawn through gas and aerosol measuring instruments aboard the aircraft and through filters for subsequent chemical analysis. The grabbag system had an aerosol $50 \%$ cut point diameter of about $4 \mu \mathrm{m}$; larger particles were lost in the inlet and on the walls of the grab bag. On many occasions, grab-bag samples were immediately followed by continuous sampling of the ambient air, allowing comparisons between the two.

[76] To avoid possible contamination from the plastic grab-bag material, a different approach was used for obtaining whole air samples of smoke plumes for subsequent analysis of hydrocarbons, halocarbons, dimethyl sulfide, and methyl nitrate. Electropolished stainless steel canisters were filled with air samples from smoke plumes using a stainless steel inlet that passed through the aircraft fuselage. 


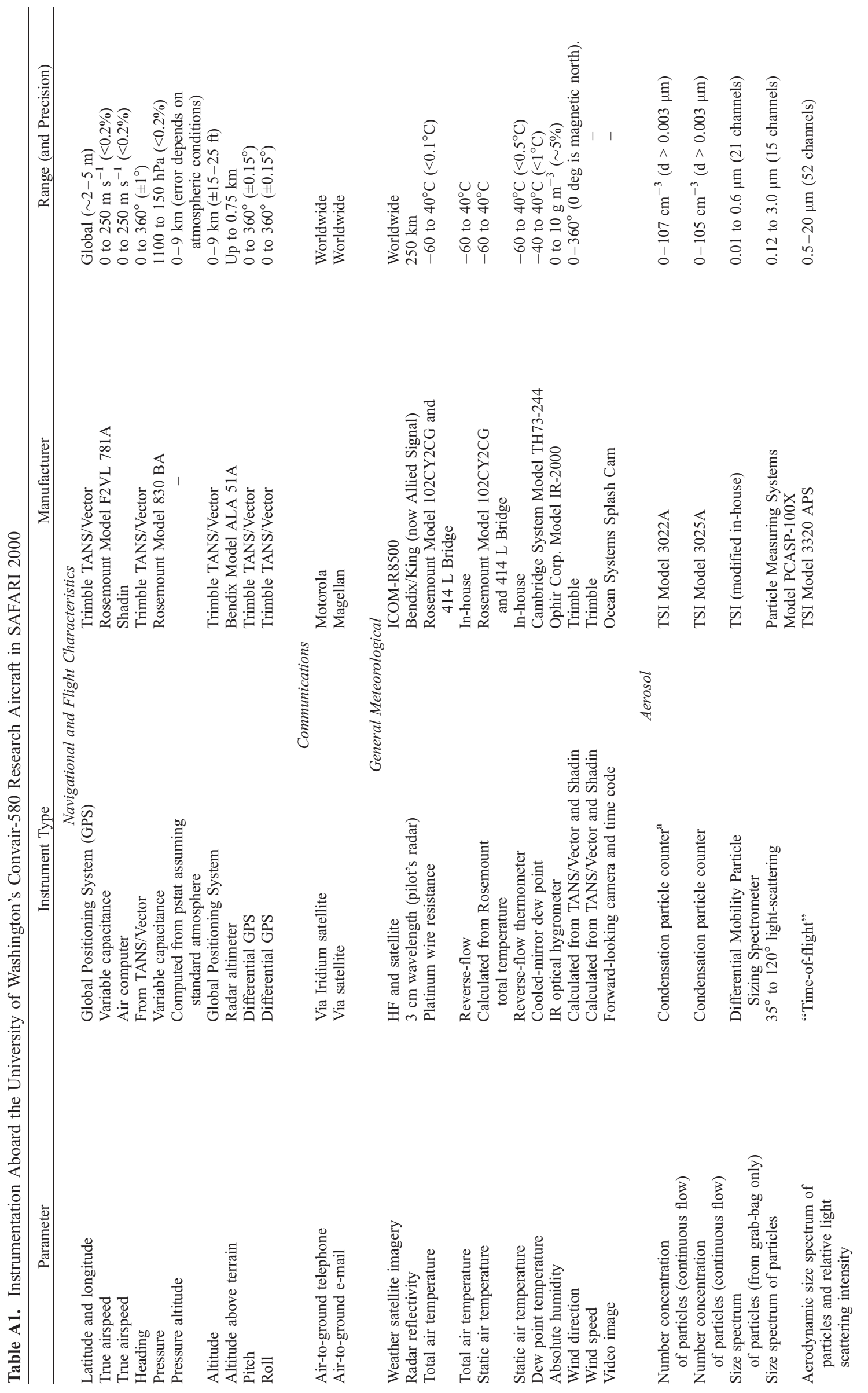




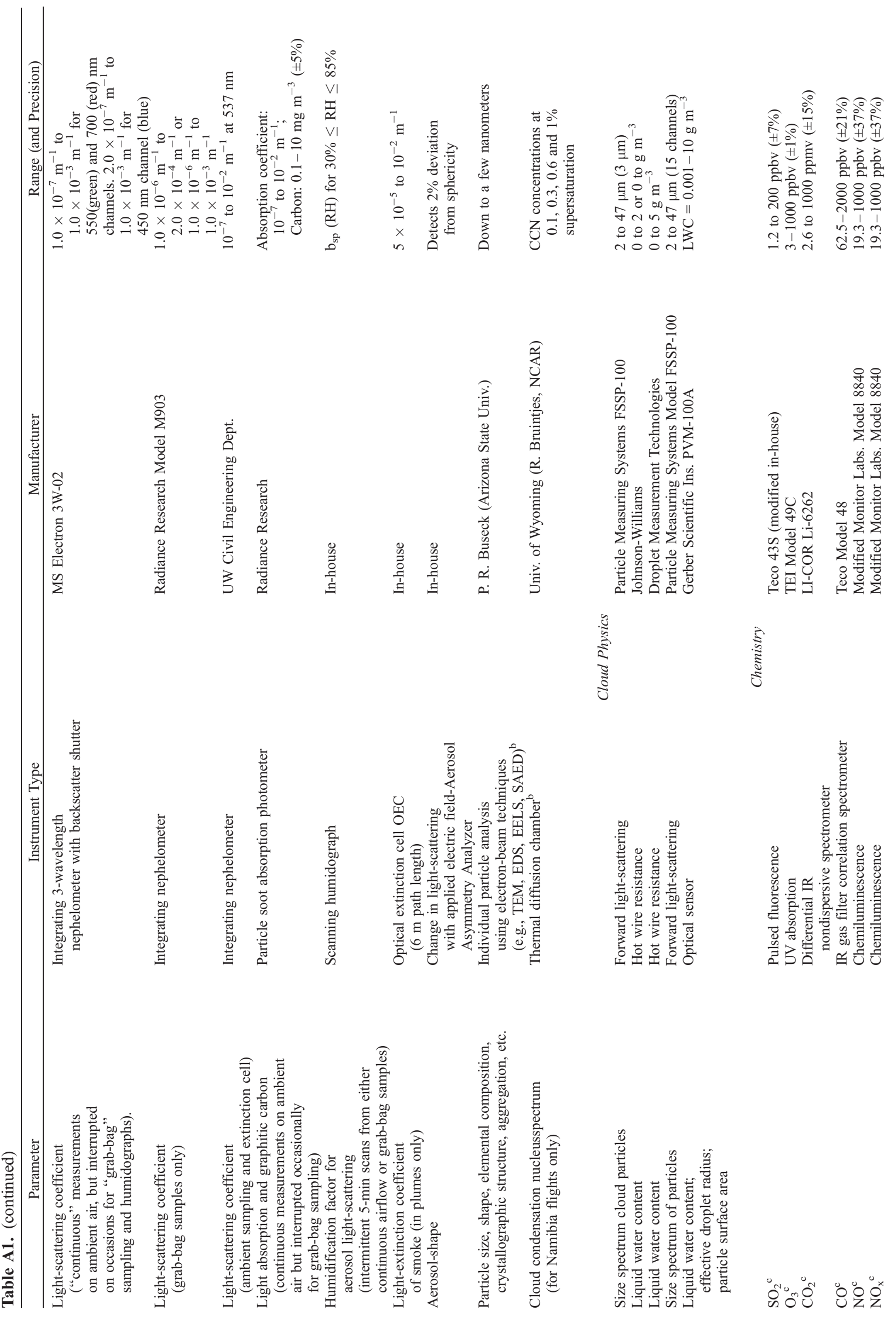




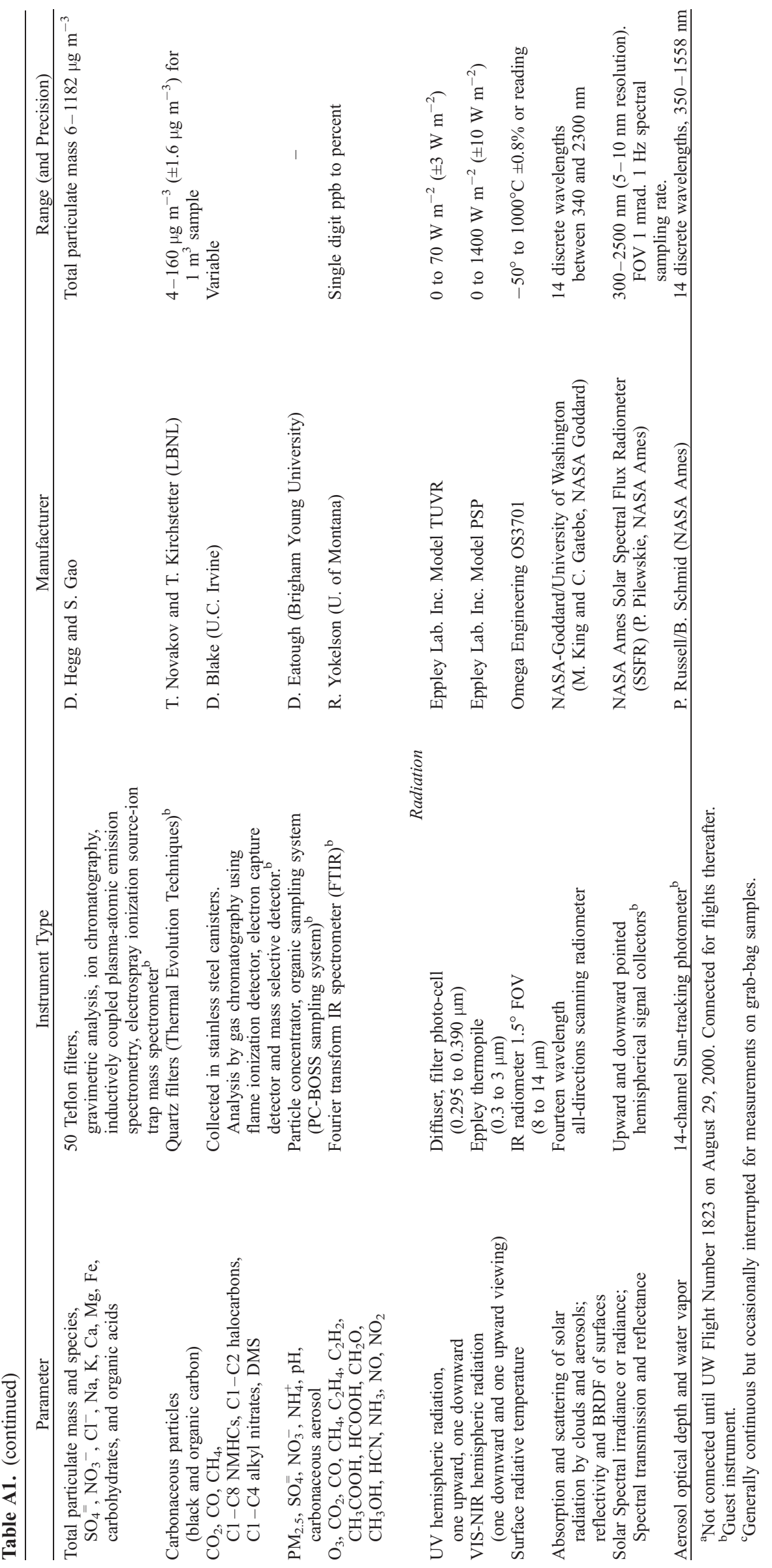


Background samples were obtained just upwind of the fires and subtracted from the mixing ratios measured in the smoke samples.

[77] The whole air samples collected in the stainless steel canisters were analyzed by gas chromatography using various techniques (see Table A1). For each sample, mixing ratios of $\mathrm{CO}_{2}$ (precision of $3 \%$ ), $\mathrm{CO}$ (precision of $10 \%$ ), $\mathrm{CH}_{4}$ (precision of $1 \%$ ), and hydrocarbons with $\mathrm{C}<11$ (precision of $10 \%$, detection limit of $3 \mathrm{ppt}$ ) were measured. The mixing ratios of five halocarbons $\left(\mathrm{CH}_{3} \mathrm{Cl}, \mathrm{CHCl}_{3}\right.$, $\mathrm{CH}_{3} \mathrm{I}, \mathrm{CH}_{3} \mathrm{Br}$, and $\mathrm{CHBr}_{3}$ ) were determined from the canister samples using gas chromatography with an electron capture detector, which were precise to within $10 \%$. Measurements of longer lived halocarbons (CFC, HCFC, and HFC) were accurate to within $2 \%$.

[78] Airborne Fourier transform infrared spectroscopy (AFTIR) was used to measure $\mathrm{CO}_{2}, \mathrm{CO}, \mathrm{NO}_{\mathrm{x}}, \mathrm{CH}_{4}$, ethene, acetylene, formaldehyde, acetic acid, formic acid, ammonia, and hydrogen cyanide (HCN) to an accuracy of $1-10 \%$. The AFTIR system design and measurement strategy is described by Yokelson et al. [2003].

[79] Particles were collected on quartz and Teflon filters. After gravimetric analysis, the Teflon filters were extracted in deionized water (HPLC grade) and analyzed by a standard ion chromatography system. This analysis yielded mass concentrations of the ions $\mathrm{Cl}^{-}, \mathrm{NO}_{3}{ }^{-}, \mathrm{SO}_{4}{ }^{2-}$ (precision within $5 \%$ ) and several organic acid species (precision within $20 \%$ ) such as oxalate $\left(\mathrm{C}_{2} \mathrm{O}_{4}{ }^{2-}\right)$. An Inductively Coupled Plasma-Atomic Emission Spectrometer was used to measure the mass concentrations of $\mathrm{Na}, \mathrm{K}, \mathrm{Ca}, \mathrm{Mg}$ and $\mathrm{Fe}$ (precision of 5\%). An electrospray ionization-ion trap mass spectrometer was used to identify and quantify carbohydrate species. Further details on the measurements of watersoluble aerosol components are given by Gao et al. [2003].

[80] Aerosol samples collected on the quartz filters were used to determine the concentration of particulate carbon. The quartz filters were baked before use at $800^{\circ} \mathrm{C}$ for at least $6 \mathrm{~h}$ to remove carbonaceous impurities, and then analyzed for total carbon (TC) content using the evolved gas analysis method [Novakov, 1981, 1982]. Further details on these procedures are given by Kirchstetter et al. [2003].

\section{A3. Airborne Flight Strategies}

[81] During the dry season in southern Africa one of the main sources of particles and gases is biomass burning. Therefore, particular attention was paid in SAFARI 2000 to obtaining measurements of the nature and amounts of particles and gases emitted from various types of biomass burning in the region. To this end, we obtained measurements in smoke from 10 fires (six prescribed and four targets of opportunity). In general, the smoke was sampled first close to the fires then at increasing distances downwind. From these measurements, emission factors (i.e., mass of species emitted per unit mass of fuel burned) can be derived using the carbon balance method [Radke et al., 1988], and the transformations of chemical species with smoke age can be determined.

[82] Airborne measurements from the UW Convair-580, obtained simultaneously with a variety of remote sensing measurements from satellites (primarily Terra), from the NASA ER-2 high flying aircraft, and from the ground (at the SAFARI 2000 instrumented sites at Skukusa, South
Africa, Inhaca Island, Mozambique, Sua Pan and Maun, Botswana, Mongu, Zambia, and Etosha Pan, Namibia), were an important component of this study. In these cases, continuous measurements of aerosols and a number of gases were obtained, from $\sim 30 \mathrm{~m}$ above ground level up to the free troposphere, below and/or above the remote sensing instruments. In addition, during the course of these vertical profiles the aircraft was generally flown back and forth along several horizontal legs $\sim 20-50 \mathrm{~km}$ in length at prescribed heights for sufficient periods of time to sample enough air through various filters for subsequent chemical analyses of the aerosols. The measurements obtained in these vertical profiles can be compared with corresponding parameters derived from remote sensing, as well as being used in a variety of column "closure" studies.

[83] Another common flight scenario, generally associated with transiting between sites, were long flights at fairly constant altitudes. Measurements from the continuously recording instruments were made on these flight legs; in addition, filter and canister samples were collected periodically. These data sets provide information on horizontal variabilities in gases, particles and radiation parameters in the mixed layer and free troposphere.

[84] To obtain measurements of BRDF with the NASACAR instrument [King et al., 1986; Gatebe et al., 2003], the aircraft was flown in a circle $\sim 2.5 \mathrm{~km}$ in diameter at $\sim 650 \mathrm{~m}$ above various surfaces and clouds. This provided the complete reflectance pattern of a surface from nadir to horizon and much of the transmittance pattern from zenith to horizon at nine narrow bands in the ultraviolet, visible and infrared.

[85] In flights off the Namibian coast, attention was focused on obtaining in situ measurements of the structures of stratus cloud during overpasses of the NASA ER-2 aircraft and Terra satellite. In these cases, the aircraft flew horizontal legs of $\sim 20 \mathrm{~km}$ below cloud base, in cloud, and above cloud top. The leg below cloud base provided measurements of cloud condensation nuclei and aerosols entering the cloud; the in-cloud leg gave measurements of cloud liquid water content and drop size spectra; and the leg above cloud top measurements of the BRDF of the cloud. Also, vertical profiles for physical and chemical measurements were obtained both off the Namibian coast and over Namibia.

\section{A4. Locations of Flights and Overview of Measurements}

[86] Figure A2 shows the general locations of the thirty research flights of the Convair-580 in SAFARI 2000. As can be seen, the flights covered a wide area of southern Africa: from Johannesburg, South Africa, in the south to Mongu, Zambia, in the north, and from the Indian Ocean in the east to the South Atlantic Ocean in the west.

[87] Table A2 lists the dates, times, general locations, and the main accomplishments of each of the Convair-580 flights in SAFARI 2000.

\section{A5. Papers in This Special Issue Describing Measurements Obtained Aboard the Convair-580 in SAFARI 2000}

[88] This Special Issue of the Journal of Geophysical Research contains a number of papers describing measurements obtained aboard the Convair-580 in SAFARI 2000. 


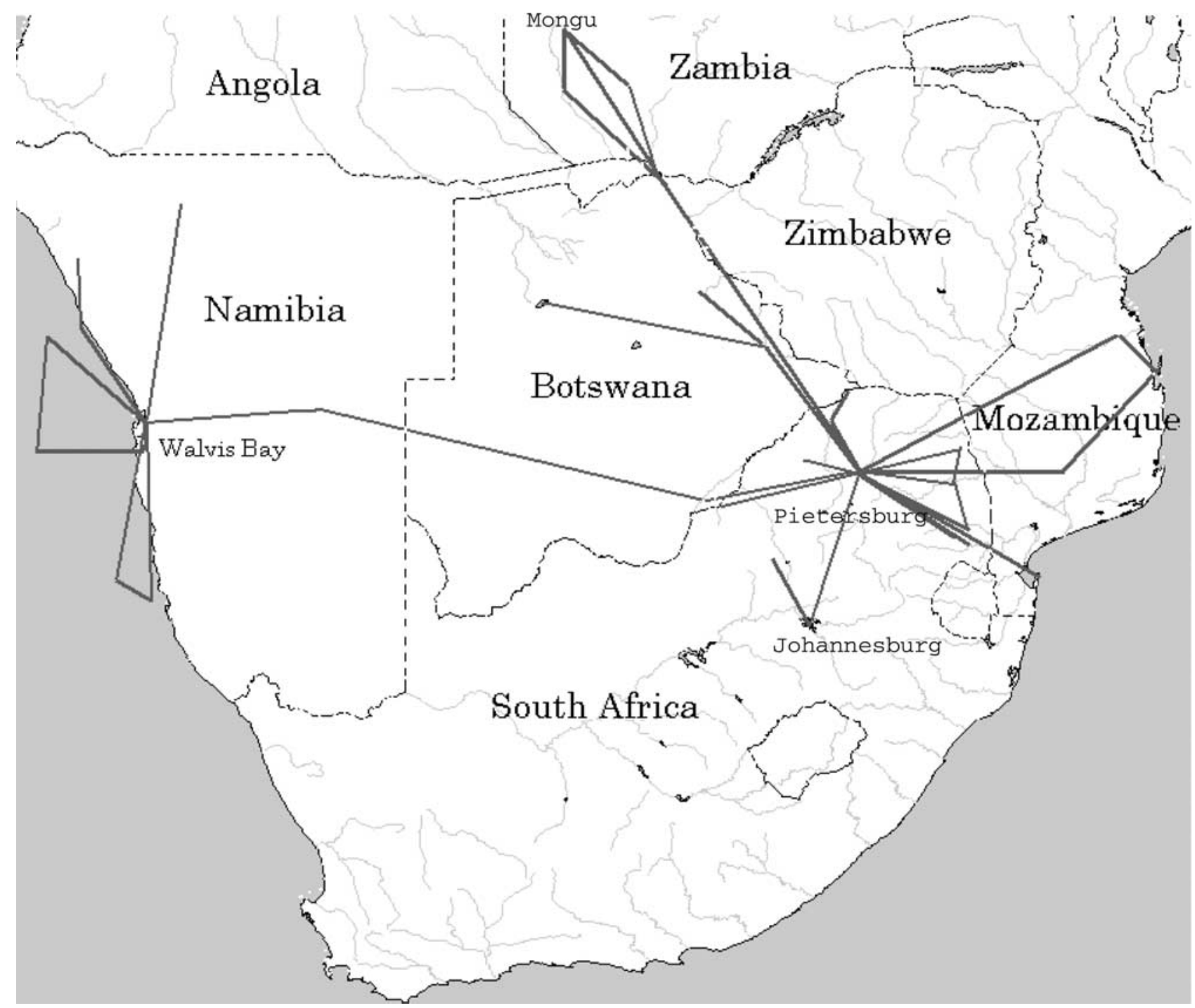

Figure A2. Approximate flight tracks (solid lines) of the University of Washington's Convair-580 research aircraft in southern Africa in the SAFARI 2000 field study.

[89] The present paper presents emission ratios and emission factors for a large number of gases and particles emitted by various types of biomass fires in southern Africa. Yokelson et al. [2003] used an FTIR aboard the Convair-580 to measure the trace gas composition of nascent, aged, and cloud-processed smoke from savanna fires. The measurements include data on the emissions of oxygenated organic compounds from tropical fires, the formation rate of ozone and acetic acid in tropical biomass-burning plumes, and trace-gas scavenging in cloud-processed smoke. Gao et al. [2003] describe the identification and quantification of water-soluble organic compounds and inorganic components in smoke and hazes along with some evolution and distribution patterns. Airborne measurements of carbonaceous particles (black carbon and organic carbon) and semivolatile organic products are described by Kirchstetter et al. [2003] and Eatough et al. [2003], respectively. The effects of relative humidity on light scattering by particles in ambient air and in the smoke plumes from biomass fires in southern Africa are described by Magi and Hobbs [2003]. Detailed information on some of the physical and chemical character- istics of individual particles sampled aboard the Convair-580 in southern Africa are described by Li et al. [2003] and Pósfai et al. [2003]. Hobbs et al. [2003] describe the effects of smoke aging on the trace gases and particles in the plume from a large prescribed biomass fire. Schmid et al. [2003] present measurements of column aerosol optical depth (AOD) and water vapor obtained with a multiwavelength Sun photometer aboard the Convair-580. They compare these measurements with ground-based lidar data, with measurements from a downlooking lidar aboard the highflying NASA ER-2 aircraft, and with satellite retrievals of AOD over land and water. Vertical profiles and aerosol light scattering, light absorption and single-scattering albedo, and comparisons of aerosol optical depths derived from in situ and Sun photometer measurements on the Convair-580, are presented by Magi and Hobbs [2003]. Thin, horizontal layers of remarkably clean air, sandwiched between heavily polluted air, were a common feature in southern Africa during SAFARI 2000. Hobbs [2003] refers to these layers as "clean air slots," he describes a case study, and offers an explanation for the propensity for clear air slots to occur in 


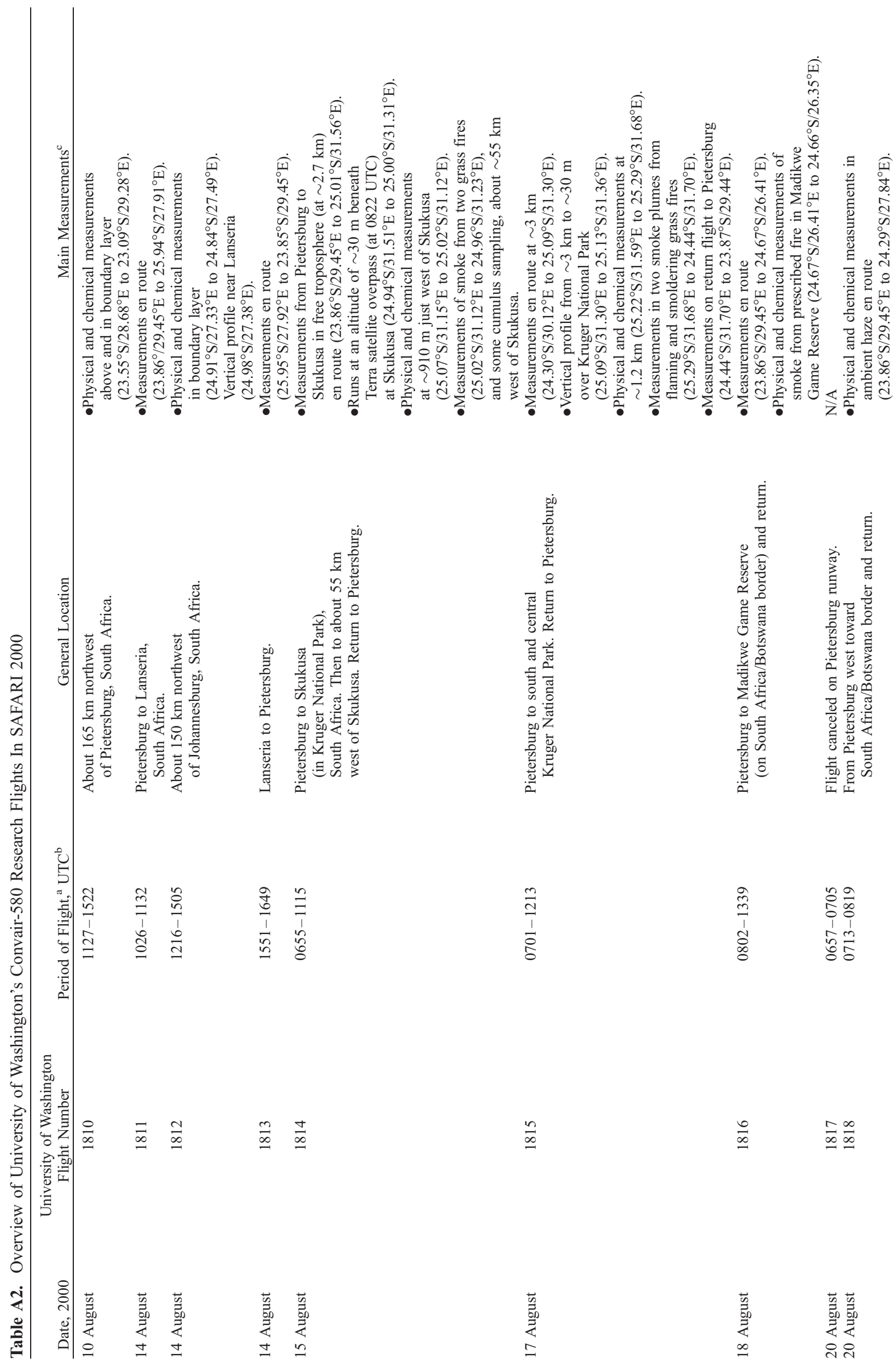




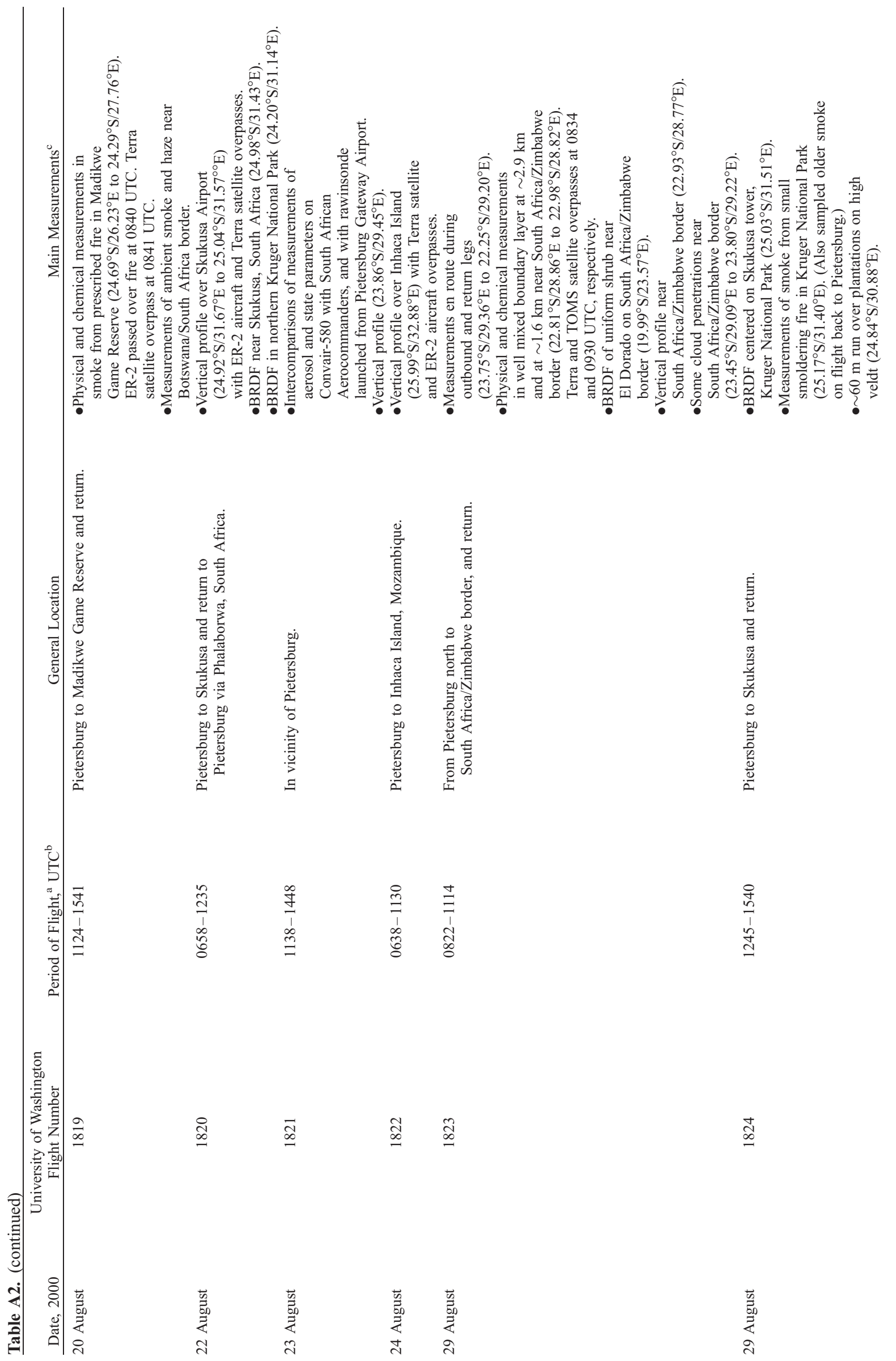




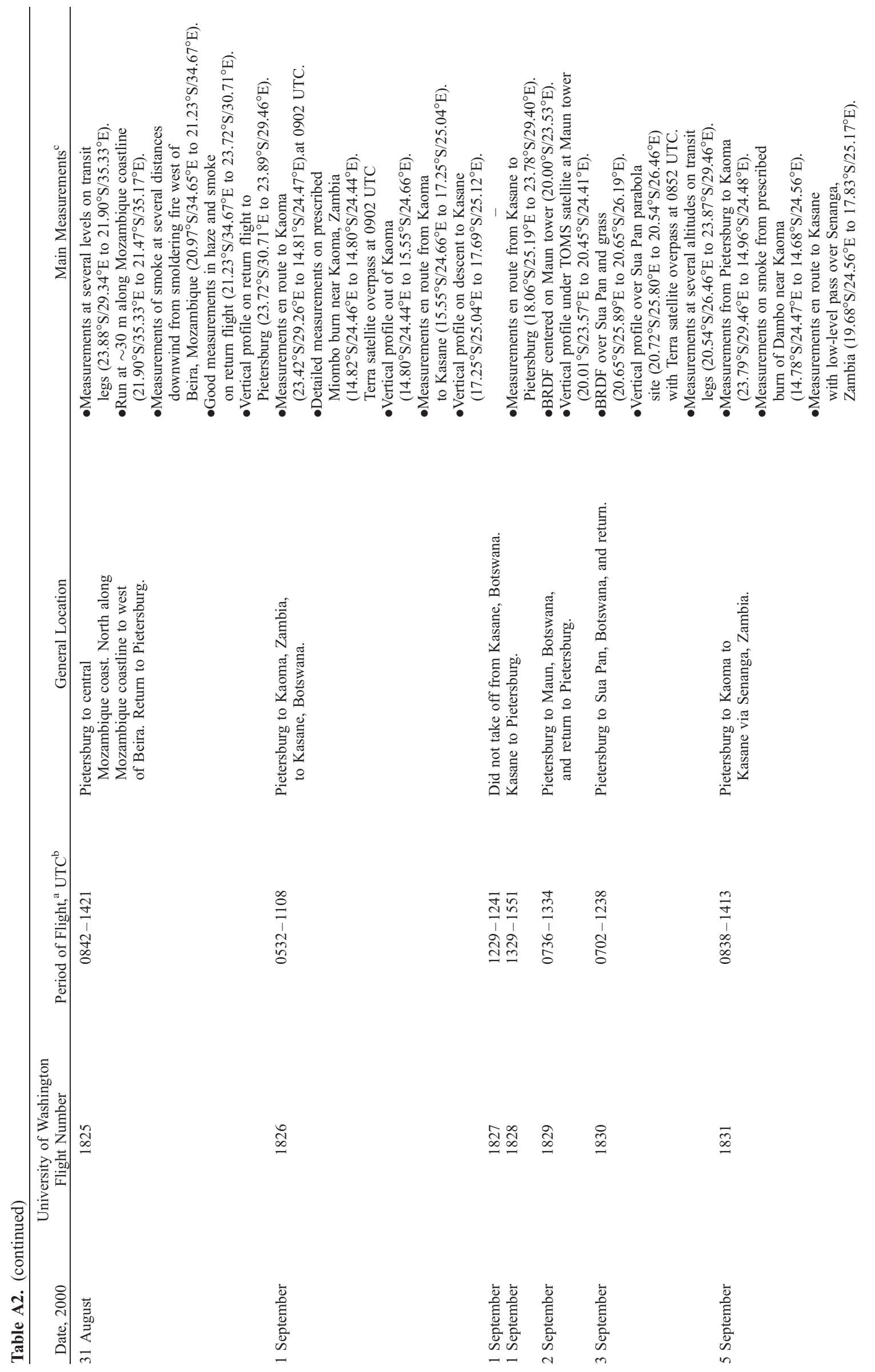




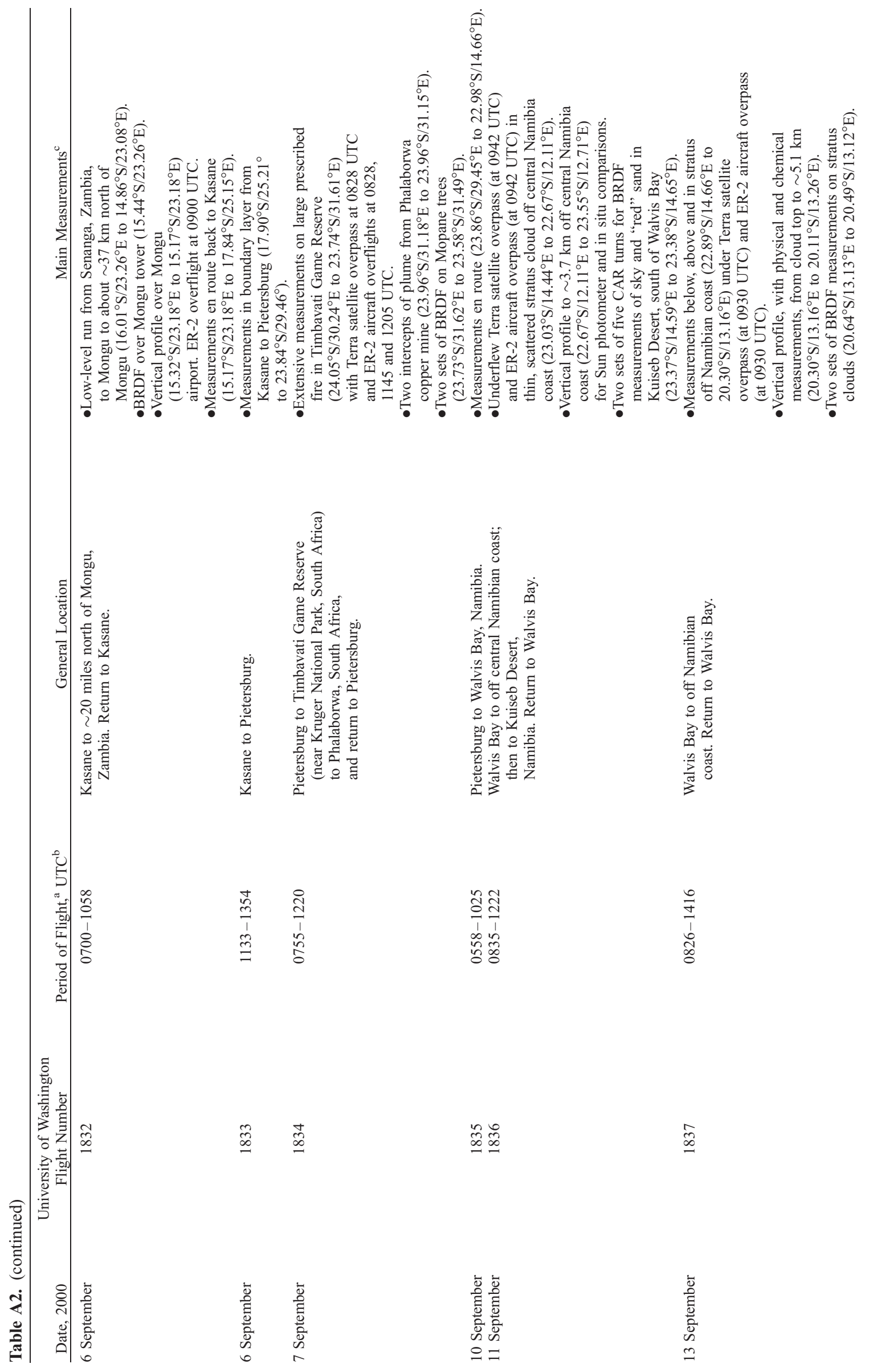




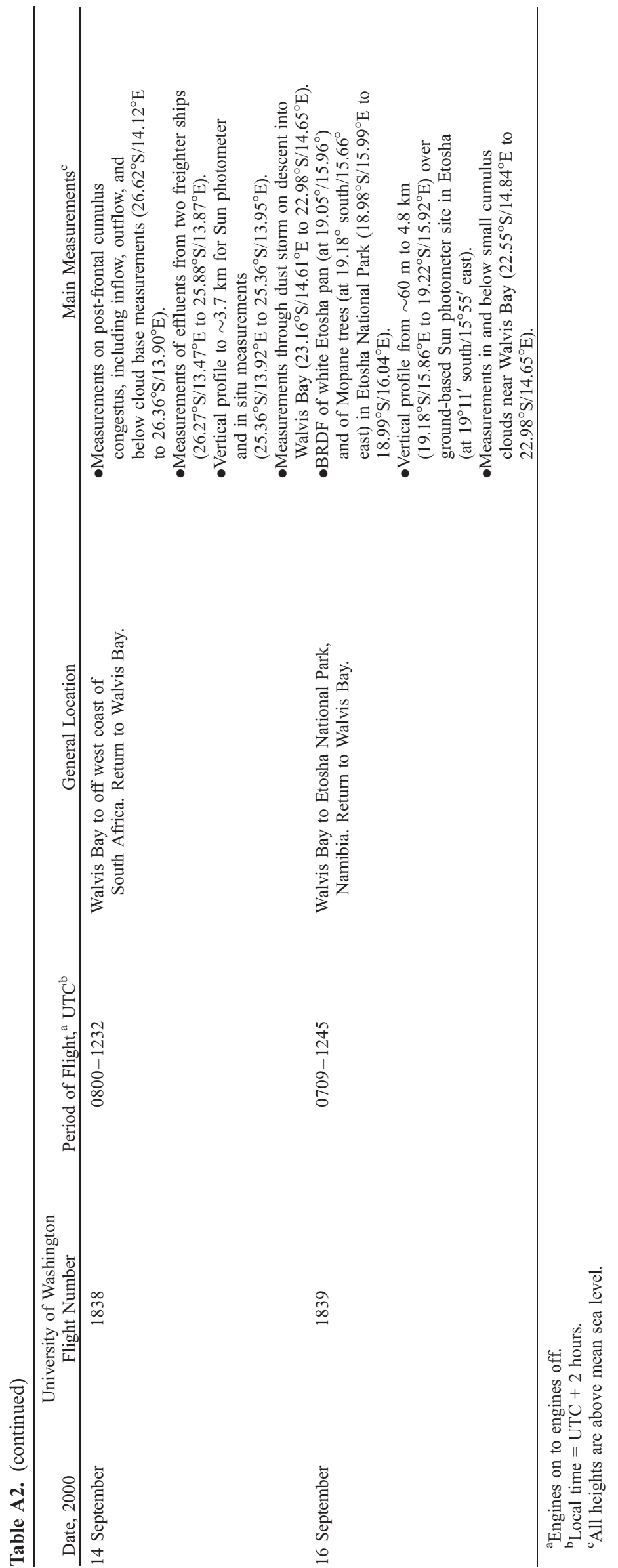


southern Africa during the dry season. Pilewskie et al. [2003] utilize the spectral radiometer measurements from the SSFR (see Table A1) to derive the effects on radiative forcing of aerosols in southern Africa during SAFARI 2000. Measurements of the BRDF and hemispherical albedo of various surfaces in southern Africa, obtained aboard the UW Convair-580, are described by Gatebe et al. [2003]. Some comparisons between in situ measurements of $\mathrm{CO}$ aboard the Convair-580 and scanning high-resolution interferometer sounder (SHIS) aboard the ER-2 aircraft are discussed by McMillan et al. [2003].

\section{A6. Future Studies}

[90] Many studies remain to be carried out utilizing data collected aboard the Convair-580 in SAFARI 2000. These studies include:

1. In situ and remote sensing measurements of vertical profiles of light scattering, light absorption and light extinction were obtained aboard the Convair-580. These measurements need to be documented and compared with each other, and with remote sensing measurements from the ground, from satellites, and from the overflying NASA ER2 aircraft.

2. Transformations of chemicals in southern Africa over both short (hours) and long (days) time periods, and in cloud-free and cloudy situations, can be explored with the data obtained on the Convair-580.

3. Measurements of the smoke from several prescribed and nonprescribed biomass fires in South Africa, Mozambique, Botswana and Zambia have yet to be studied in detail.

4. Modeling of emissions from biomass fires and their transformations and comparisons with measurements obtained aboard the Convair-580 in SAFARI 2000.

5. The spectral and broadband albedo (and BRDF) of various surfaces and clouds in southern Africa.

6. Transformations of pollutants from the interior of southern Africa to the South Atlantic Ocean.

7. The microstructures of stratus and cumulus clouds off the Namibian coast, and comparisons of the in situ airborne measurements with simultaneous remote sensing measurements from the NASA ER-2 aircraft and the Terra satellite.

8. Vertical profiles of particles and gases through a number of clean air slots should be studied in an effort to determine the mechanisms by which such slots are maintained over long time periods and over large areas.

9. Analyses of the emissions from two tanker ships, which were measured off the Namibian coast.

[91] Acknowledgments. We thank all members of the UW-CARG for help in obtaining measurements, and Dan Jaffe for help in calibrating the gas instruments. Thanks are also due to the organizers of the SAFARI 2000 Southern African Regional Science Initiative, and all those on the ground and in the field, who contributed to this study. This research was supported by grants NAG5-9022 and NAG5-7675 from NASA's Radiation Science Program, grants NCC5-550 and NASI-18940 from the NASA EOS Program, and grants ATM-9901624 and ATM-9900494 from NSF's Division of Atmospheric Sciences.

\section{References}

Andreae, M. O., and P. Merlet, Emission of trace gases and aerosols from biomass burning, Global Biogeochem. Cycles, 15, 955-966, 2001.

Andreae, M. O., E. Atlas, H. Cachier, W. R. Cofer III, G. W. Harris, G. Helas, R. Koppmann, J. Lacaux, and D. Ward, Trace gas and aerosol emissions from savanna fires, in Biomass Burning and Global Change, vol. 1, edited by J. S. Levine, pp. 278-295, MIT Press, Cambridge, Mass., 1996.
Andreae, M. O., et al., Airborne studies of aerosol emissions from savanna fires in southern Africa: Aerosol chemical composition, J. Geophys. Res., 103, 32,114-32,128, 1998.

Bertschi, I., R. J. Yokelson, D. E. Ward, J. G. Goode, R. Babbitt, R. A Susott, and W. M. Hao, Trace gas and particle emissions from fires in large diameter and belowground biomass fuels, J. Geophys. Res., 108(D13), 8472, doi:10.1029/2002JD002100, 2003

Blake, N. J., D. R. Blake, B. C. Sieve, T.-Y. Chen, F. S. Rowland, J. E. Collins Jr., G. W. Sachse, and B. E. Anderson, Biomass burning emissions and vertical distribution of atmospheric methyl halides and other reduced carbon gases in the South Atlantic region, J. Geophys. Res., 101, 24,151-24,164, 1996

Cachier, H., C. Liousse, M. Pertuisot, A. Gaudichet, F. Echalar, and J. Lacaux, African fire particulate emissions and atmospheric influence, in Biomass Burning and Global Change, vol. 1, edited by J. S. Levine, pp. 428-440, MIT Press, Cambridge, Mass., 1996.

Cofer, W. R., III, J. S. Levine, E. L. Winstead, D. R. Cahoon, D. I. Sebacher, J. P. Pinto, and B. J. Stocks, Source composition of trace gases released during African savanna fires, J. Geophys. Res., 101, 23,59723,602, 1996.

Colman, J. J., A. L. Swanson, S. Meinardi, B. C. Sive, D. R. Blake, and F. S. Rowland, Description of the analysis of a wide range of volatile organic compounds in whole air samples collected during PEM-Tropics A and B, Anal. Chem., 73, 3723-3731, 2001.

Crutzen, P. J., and M. O. Andreae, Biomass burning in the tropics: Impact on atmospheric chemistry and biogeochemical cycles, Science, 250, 1669-1678, 1990.

Delmas, R., On the emission of carbon, nitrogen and sulfur in the atmosphere during bushfires in intertropical savannah zones, Geophys. Res. Lett., 9, 761-764, 1982.

Eatough, D. J., N. L. Eatough, Y. Pang, S. Sizemore, T. W. Kirchstetter, T. Novakov, and P. V. Hobbs, Semivolatile particulate organic material in southern Africa during SAFARI 2000, J. Geophys. Res., 108(D13), 8479, doi:10.1029/2002JD002296, 2003.

Ferek, R. J., J. S. Reid, P. V. Hobbs, D. R. Blake, and C. Liousse, Emission factors of hydrocarbons, halocarbons, trace gases and particles from biomass burning in Brazil, J. Geophys. Res., 103, 32,107-32,118, 1998.

Fishman, J., K. Fakhruzzaman, B. Cros, and D. Nganga, Identification of widespread pollution in the southern hemisphere deduced from satellite analyses, Science, 252, 1693-1696, 1991.

Fishman, J., J. M. Hoell, R. D. Bendura, R. J. McNeil, and V. W. J. H. Kirchhoff, NASA GTE TRACE A experiment (Sept.-Oct. 1992): Overview, J. Geophys. Res., 101, 23,869-23,879, 1996.

Gao, S., D. A. Hegg, P. V. Hobbs, T. W. Kirchstetter, B. I. Magi, and M. Sadilek, Water-soluble organic components in aerosols associated with savanna fires in southern Africa: Identification, evolution and distribution, J. Geophys. Res., 108, doi:10.1029/2002JD002324, in press, 2003.

Gatebe, C. K., M. D. King, S. Platnick, G. T. Arnold, E. F. Vermote, and B. Schmid, Airborne spectral measurements of surface-atmosphere anisotropy for several surfaces and ecosystems over southern Africa, J. Geophys. Res., 108, doi:10.1029/2002JD002397, in press, 2003.

Goode, J. G., R. J. Yokelson, R. A. Susott, and D. E. Ward, Trace gas emissions from laboratory biomass fires measured by open-path Fourier transform infrared spectroscopy: Fires in grass and surface fuels, J. Geophys. Res., 104, 21,237-21,245, 1999.

Goode, J. G., R. J. Yokelson, D. E. Ward, R. A. Susott, R. E. Babbitt, M. A. Davis, and W. M. Hao, Measurements of excess $\mathrm{O}_{3}, \mathrm{CO}_{2}, \mathrm{CO}, \mathrm{CH}_{4}$, $\mathrm{C}_{2} \mathrm{H}_{4}, \mathrm{C}_{2} \mathrm{H}_{2}, \mathrm{HCN}, \mathrm{NO}, \mathrm{NH}_{3}, \mathrm{HCOOH}, \mathrm{CH}_{3} \mathrm{COOH}, \mathrm{HCHO}$ and $\mathrm{CH}_{3} \mathrm{OH}$ in 1997 Alaskan biomass burning plumes by airborne Fourier transform infrared spectroscopy (AFTIR), J. Geophys. Res., 105, 22,147-22,166, 2000 .

Gundel, L. A., R. L. Dod, H. Rosen, and T. Novakov, The relationship between optical attenuation and black carbon concentrations for ambient and source particles, Sci. Total Environ., 36, 197-202, 1984.

Hao, W. M., and M. H. Liu, Spatial and temporal distribution of tropical biomass burning, Global Biogeochem. Cycles, 8, 495-503, 1994.

Herring, J. A., Radiative properties, dynamics and chemical evolution of the smoke from the 1991 Kuwait oil fires, Ph.D. dissertation, 301 pp., Univ. of Wash., Seattle, 1994.

Hobbs, P. V., Introduction to Atmospheric Chemistry, Cambridge Univ. Press, New York, 2000.

Hobbs, P. V., Clean air slots amid dense atmospheric pollution in southern Africa, J. Geophys. Res., 108, doi:10.1029/2002JD002156, in press, 2003.

Hobbs, P. V., P. Sinha, R. J. Yokelson, T. J. Christian, D. R. Blake, S. Gao, T. W. Kirchstetter, T. Novakov, and P. Pilewskie, Evolution of gases and particles from a savanna fire in South Africa, J. Geophys. Res., 108, doi:10.1029/2002JD002352, in press, 2003

Hurst, D. F., D. W. T. Griffith, J. N. Carras, D. J. Williams, and P. J. Fraser, Measurements of trace gases emitted by Australian savanna fires during the 1990 dry season, J. Atmos. Chem., 18, 33-56, 1994. 
King, M. D., M. G. Strange, P. Leone, and L. R. Blaine, Multiwavelength scanning radiometer for airborne measurements of scattered radiation in clouds, J. Atmos. Oceanic Technol., 3, 513-522, 1986.

Kirchstetter, T. W., C. E. Corrigan, and T. Novakov, Laboratory and field investigation of the adsorption of gaseous organic compounds onto quartz filters, Atmos. Environ., 35, 1663-1671, 2001.

Kirchstetter, T. W., T. Novakov, P. V. Hobbs, and B. Magi, Airborne measurements of carbonaceous aerosols in southern Africa during the dry biomass burning season, J. Geophys. Res., 108(D13), 8476, doi:10.1029/2002JD002171, 2003.

Kliner, D. A. V., B. C. Daube, J. D. Burley, and S. C. Wofsy, Laboratory investigation of the catalytic reduction $\mathrm{NO}_{\mathrm{y}}$, J. Geophys. Res., 102 , 10,759-10,776, 1997.

Lacaux, J., R. A. Delmas, B. Cros, B. Lefeivre, and M. O. Andreae, Influence of biomass burning on precipitation chemistry in the equatorial forests of Africa, in Global Biomass Burning, edited by J. S. Levine, pp. 167-173, MIT Press, Cambridge, Mass., 1991.

Le Canut, P., M. O. Andreae, G. W. Harris, F. G. Wienhold, and T. Zenker, Airborne studies of emissions from savanna fires in southern Africa, 1 , Aerosol emissions measured with a laser optical particle counter, J. Geophys. Res., 101, 23,615-23,630, 1996.

Li, B. Q., D. J. Jacob, I. Bey, R. M. Yantosca, Y. J. Zhao, Y. Kondo, and J. Notholt, Atmospheric hydrogen cyanide (HCN): Biomass burning source, ocean sink?, Geophys. Res. Lett., 27, 357-360, 2000.

Li, J., M. Pósfai, P. V. Hobbs, and P. R. Buseck, Individual aerosol particles from biomass burning in southern Africa: 2. Compositions and aging of inorganic particles, J. Geophys. Res., 108, doi:10.1029/2002JD002310, in press, 2003.

Lobert, J. M., W. C. Keene, J. A. Logan, and R. Yevich, Global chlorine emissions from biomass burning: Reactive chlorine emissions inventory, J. Geophys. Res., 104, 8373-8389, 1999.

Logan, J. A., M. J. Prather, S. C. Wofsy, and M. B. McElroy, Tropospheric chemistry: A global perspective, J. Geophys. Res., 86, 7210-7254, 1981.

Magi, B. I., and P. V. Hobbs, The effects of humidity on aerosols in southern Africa during the biomass burning season, J. Geophys. Res., 108, doi:10.1029/2002JD002144, in press, 2003.

Magi, B., P. V. Hobbs, B. Schmid, and J. Redemann, Vertical profiles of light scattering, light absorption, and single-scattering albedo during the dry, biomass burning season in southern Africa and comparisons of in situ and remote sensing measurements of aerosol optical depths, J. Geophys. Res., 108, doi:10.1029/2002JD002361, in press, 2003.

Mano, S., and M. O. Andreae, Methyl bromide from biomass burning, Science, 263, 1255-1256, 1994

Mason, S. A., R. J. Field, R. J. Yokelson, M. A. Kochivar, M. R. Tinsley, D. E. Ward, and W. M. Hao, Complex effects arising in smoke plume simulations due to inclusion of direct emissions of oxygenated organic species from biomass combustion, J. Geophys. Res., 106, 12,527-12,539, 2001.

Mazurek, M. A., W. R. Cofer III, and J. S. Levine, Carbonaceous aerosols from prescribed burning of a boreal forest ecosystem, in Global Biomass Burning: Atmospheric, Climatic and Biospheric Implications, edited by J. S. Levine, pp. 258-263, MIT Press, Cambridge, Mass., 1991.

McKenzie, L. M., D. E. Ward, and W. M. Hao, Chlorine and bromine in the biomass of tropical and temperate ecosystems, in Biomass Burning and Global Change, vol. 1, edited by J. S. Levine, pp. 240-248, MIT Press, Cambridge, Mass., 1996.

McMillan, W. W., et al., Tropospheric carbon monoxide measurements from the Scanning High-Resolution Interferometer Sounder on 7 September 2000, in southern Africa during SAFARI 2000, J. Geophys. Res., 108, doi:10.1029/2002JD002335, 2003.

Novakov, T., Microchemical characterization of aerosols, in Nature, Aim and Methods of Microchemistry, edited by H. Malissa, M. Grasserbaure, and R. Belcher, pp. 141-165, Springer-Verlag, New York, 1981

Novakov, T., Soot in the atmosphere, in Particulate Carbon: Atmospheric Life Cycle, edited by G. T. Wolff and R. L. Klimish pp. 19-41, Plenum, New York, 1982

Pilewskie, P., J. Pommier, R. Bergstrom, W. Gore, S. Howard, M. Robbette, B. Schmid, P. V. Hobbs, and S.-C. Tsay, Solar spectral radiative forcing during the Southern African Regional Science Initiative, J. Geophys Res., 108, doi:10.1029/2002JD002411, in press, 2003.

Pósfai, M., R. Simonics, J. Li, P. V. Hobbs, and P. B. Buseck, Individual aerosol particles from biomass burning in southern Africa: 1. Compositions and size distributions of carbonaceous particles, J. Geophys. Res. 108, doi:10.1029/2002JD002291, in press, 2003.

Quay, P. D., et al., Carbon isotopic composition of atmospheric methane: Fossil and biomass burning strengths, Global Biogeochem. Cycles, 5, $25-47,1991$.

Radke, L. F., D. A. Hegg, J. H. Lyons, C. A. Brock, and P. V. Hobbs, Airborne measurements on smokes from biomass burning, in Aerosols and Climate, edited by P. V. Hobbs and M. P. McCormick, pp. 411-422, A. Deepak, Hampton, Va., 1988.
Reid, J. S., P. V. Hobbs, R. J. Ferek, D. R. Blake, J. V. Martins, M. R. Dunlap, and C. Liousse, Physical, chemical, and optical properties of regional hazes dominated by smoke in Brazil, J. Geophys. Res., 103, 32,059-32,080, 1998.

Rodgers, C. F., J. G. Hudson, B. Zielinska, R. L. Tanner, J. Hallett, and J. G. Watson, Cloud condensation nuclei from biomass burning, in Global Biomass Burning, edited by J. S. Levine, pp. 431-438, MIT Press, Cambridge, Mass., 1991.

Rosen, H., and T. Novakov, Optical-transmission through aerosol deposits on diffusely reflective filters - A method for measuring the absorbing component of aerosol-particles, Appl. Opt., 22, 1265-1267, 1983.

Schmid, B., et al., Coordinated airborne, spaceborne, and ground-based measurements of massive, thick aerosol layers during the dry season in southern Africa, J. Geophys. Res., 108, doi:10.1029/2002JD002297, in press, 2003. Seinfeld, J. H., and S. N. Pandis, Atmospheric Chemistry and Physics, John Wiley, New York, 1998.

Susott, R. A., G. J. Olbu, S. P. Baker, D. E. Ward, J. B. Kauffmann, and R. W. Shea, Carbon, hydrogen, nitrogen, and thermogravimetric analysis of tropical ecosystem biomass, in Biomass Burning and Global Change, vol. 1, edited by J. S. Levine, pp. 249-259, MIT Press, Cambridge, Mass., 1996. Thompson, A. M., K. E. Pickering, D. P. McNamara, M. R. Schoeberl, R. D. Hudson, J. H. Kim, E. V. Browell, V. W. J. H. Kirchhoff, and D. Nganga, Where did tropospheric ozone over southern Africa and the tropical Atlantic come from in October 1992? Insights from TOMS, GTE TRACE A, and SAFARI 1992, J. Geophys. Res., 101, 24,251-24,278, 1996.

Turpin, B. J., J. J. Huntzicker, and S. V. Hering, Investigation of the organic aerosol sampling artifacts in the Los Angeles basin, Atmos. Environ., 28, 3061-3071, 1994.

Ward, D. E., and W. M. Hao, Air toxic emissions from burning of biomass globally-Preliminary estimates, paper presented at Annual Meeting and Exhibition, Air and Waste Management Association, Vancouver, British Columbia, 1992.

Ward, D. E., and C. C. Hardy, Smoke emissions from wildland fires, Environ. Int., 17, 117-134, 1991.

Ward, D. E., and L. F. Radke, Emissions measurements from vegetation fires: A comparative evaluation of methods and results, in Fire in the Environment: The Ecological, Atmospheric, and Climatic Importance of Vegetation Fires, edited by P. J. Crutzen and J. G. Goldammer, pp. 5376, John Wiley, New York, 1993.

Warneck, P., Chemistry of the Natural Atmosphere, Academic, San Diego, Calif., 2000.

White, F., UNESCO/AETFAT/UNSO Vegetation Map of Africa, UNESCO, Paris, 1981.

White, F., Vegetation of Africa, UNESCO, Paris, 1983.

Winklmayer, W., G. P. Reischl, A. O. Lindner, and A. Berner, A new electromobility spectrometer for the measurement of the aerosol size distributions in the size ranges of 1 to 1,000 nm, J. Geophys. Res., 22, 289-296, 1991.

Yokelson, R. J., D. W. T. Griffith, and D. W. Ward, Open-path Fourier transform infrared studies of large-scale laboratory biomass fires, J. Geophys. Res., 101, 21,067-21,080, 1996

Yokelson, R. J., J. G. Goode, D. E. Ward, R. A. Susott, R. E. Babbitt, D. D. Wade, I. Bertschi, W. W. T. Griffith, and W. M. Hao, Emissions of formaldehyde, acetic acid, methanol, and other trace gases from biomass fires in North Carolina measured by airborne Fourier transform infrared spectroscopy, J. Geophys. Res., 104, 30,109-32,125, 1999.

Yokelson, R. J., I. T. Bertschi, T. J. Christian, P. V. Hobbs, D. E. Ward, and W. M. Hao, Trace gas measurements in nascent, aged, and cloud-processed smoke from African savanna fires by airborne Fourier transform infrared spectroscopy (AFTIR), J. Geophys. Res., 108(D13), 8478, doi:10.1029/2002JD002322, 2003.

I. T. Bertschi, Interdisciplinary Arts and Sciences, University of Washington, 18115 Campus Way NE, Bothell, WA 98011, USA. (isaacpb@ u.washington.edu)

D. R. Blake and I. J. Simpson, Department of Chemistry, University of California, Irvine, CA 92697, USA.(dblake@orion.oac.uci.edu; isimpson@) uci.edu)

S. Gao, Department of Chemistry, University of Washington, Box 351700, Seattle, WA 98195-1700, USA. (sgao@u.washington.edu)

P. V. Hobbs (corresponding author) and P. Sinha, Department of Atmospheric Sciences, University of Washington, Box 351640, Seattle, WA 98195-1640, USA. (phobbs@atmos.washington.edu; psinha@atmos. washington.edu)

T. W. Kirchstetter and T. Novakov, Lawrence Berkeley National Laboratory, 1 Cyclotron Road, Berkeley, CA 94720, USA. (twkirchstetter@) lbl.gov; tnovakov@lbl.gov)

R. J. Yokelson, Department of Chemistry, University of Montana, Missoula, MT 59812, USA. (byok@selway.umt.edu) 